\title{
Articles
}

\section{Causation and Attenuation in the Slavery Reparations Debate}

\author{
By KaIMIPONo DaVid WENGER*
}

\begin{abstract}
T The MOVEMENT FOR SLAVERY reparations is struggling. Scholars continue to write about reparations, ${ }^{1}$ but they seem increasingly to
\end{abstract}

* Assistant Professor, Thomas Jefferson School of Law. I was aided by helpful comments from Al Brophy, Deven Desai, Dave Hoffman, Anders Kaye, Linda Keller, Nate Oman, Tony Sebok, Ben Templin, and Hon. Jack B. Weinstein. I also received helpful comments from participants at the Faculty Workshop on Ethical, Economic and Social Issues in Mass Torts, sponsored by Brooklyn and Cardozo Law Schools. Particular thanks are due to Paul Saunders, Tim Cameron, and Cravath, Swaine and Moore LLP for providing me with a part-time work schedule that facilitated the research and drafting of this Article. Thanks to Jenny Yun for excellent editorial suggestions.

This Article expresses my personal views, not those of my employer or any former employer, or anyone who commented on it. Special thanks to my wife Mardell Wenger for her continuous support, and to my children Sullivan, Kace, and Indigo Wenger for their cheerful and contagious enthusiasm.

1. See generally Kaimipono David Wenger, Slavery as a Takings Clause Violation, 53 AM. U. L. Rev. 191, 193 nn.4-5 (2003) (collecting legal scholarship addressing reparations); Alfred L. Brophy, Reparations Talk: Reparations for Slavery and the Tort Law Analogy, 24 B.C. THIRD WORLD L.J. 81, 82-84 (2004) (noting advances in reparations discussion) [hereinafter Brophy, Reparations Talk]; Alfred L. Brophy, Some Conceptual and Legal Problems in Reparations for Slavery, 58 N.Y.U. ANN. SuRv. AM. L. 497, 505-09 (2002) (discussing development of reparations theory) [hereinafter Brophy, Some Problems].

Some of the major reparations pieces in recent years include RANDALL RoBINSON, THE Debt: What America Owes to Blacks (2001); Should America Pay?: Slavery and the Raging Debate on Reparations (Raymond A. Winbush ed., 2003) [hereinafter Should AMERICA PAY?]; Mari J. Matsuda, Looking to the Bottom: Critical Legal Studies and Reparations, 22 HaRv. C.R.-C.L. L. Rev. 323 (1987); and reparations symposia at New York University (see Symposium, A Dream Deferred: Comparative and Practical Considerations for the Black Reparations Movement, 58 N.Y.U. ANN. SuRv. AM. L. 447 (2002)); the University of Memphis (see Symposium, 33 U. Mem. L. Rev. 245 (2003)); Boston College (see Symposium, 24 B.C. THIRD WORLD L.J. 1 (2004)); Boston University (see Symposium, The Jurisprudence of Slavery Reparations, 84 B.U. L. REv. 1135 (2004)); Harvard (see Symposium, 20 HARV. BlackLeTter L.J. 17 (2004); and Boalt Hall (see Symposium, 6 Arr.-AM. L. \& PoL'y ReP. 1 (2004)). Modern legal reparations literature is generally acknowledged to have begun with Professor Boris Bittker's work. See Boris Bittker, The Case for Black Reparations (Beacon Press 2d ed. 2003) (1973). 
make up the majority of the bandwagon. The media is sometimes ambivalent and occasionally hostile. ${ }^{2}$ The lukewarm media reception mirrors societal feelings in general. ${ }^{3}$ Proposed legislation has failed to advance in Congress. ${ }^{4}$ Recently, in a closely watched consolidated case, a federal court dismissed reparations claims ${ }^{5}-$ a development that could signal the death knell of all slavery reparations litigation.

Why does the theory of reparations often seem to be divorced from the reality? Even as "reparations talk" 6 becomes more prevalent in legal academia, a serious gap exists between much of the scholarly writing on reparations and the real world decisions. ${ }^{7}$ This disjunct may have many sources; one major contributor is the difficult nature of establishing causation in reparations cases. This Article will address

2. See, e.g., Kevin Merida, Did Freedom Alone Pay a Nation's Debt? Rep. John Conyers Jr. Has a Question. He's Willing to Wait a Long Time for the Right Answer, WASH. Post, Nov. 23, 1999, at Cl; see also Vincene Verdun, If the Shoe Fits, Wear It: An Analysis of Reparations to African Americans, 67 TuL. L. REv. 597, 607 n.29 (collecting media accounts); Wenger, supra note 1 , at $194 \mathrm{nn} .6-7$ (same).

3. Polls show that overwhelming majorities of whites oppose reparations, while Blacks support reparations. See Alfred Brophy, The Cultural War over Reparations for Slavery, 53 DePaul L. Rev. 1181, 1182-85 (2004) [hereinafter Brophy, Cultural War] (discussing statistics); see also Lee A. Harris, "Reparations" as a Dirty Word: The Norm Against Slavery Reparations, 33 U. MEM. L. REv. 409, 410 n.9 (2003) (discussing these and other poll results). See generally Taunya Lovell Banks, Exploring White Resistance to Racial Reconciliation in the United States, 55 Rutgers L. Rev. 903, 915-19 (2003) (discussing demographics of Americans opposed to reparations); Michael Kranish, Blacks Rally on Capital for Slavery Reparations: Farrakhan Seeks Transfer of Land, BosTON GLOBE, Aug. 18, 2002, at A3 (discussing these findings from the CNN/USA Today/Gallup Poll).

4. Representative John Conyers, a Michigan Democrat, first introduced a bill in 1989 that would have established a commission to study the effects of slavery and recommend appropriate remedies. The bill died in committee and has been reintroduced (and repeatedly killed) every Congress since then. See H.R. 40, 108th Cong. (2003); H.R. 40, 107th Cong. (2001); H.R. 40, 106th Cong. (1999); H.R. 40, 105th Cong. (1997); H.R. 891, 104th Cong. (1995); H.R. 40, 103d Cong. (1993); H.R. 1684, 102d Cong. (1991); H.R. 3745, 101st Cong. (1989). Reprasentative Conyers has stated, "I have re-introduced H.R. 40 every Congress since 1989, and will continue to do so until it's passed into law." John Conyers, Jr., U.S. Representative, The Commission to Study Reparations Proposals for African Americans Act, Statement Before the Briefing on the Impact of Slavery on African Americans Today (Apr. 6, 2005), available at http://www.house.gov/conyers/news_reparations.htm; see also Verdun, supra note 2, at 606-07 \& n.28 (discussing proposed legislation); Wenger, supra note 1, at 194 n.6 (same).

5. In re African-Am. Slave Descendants Litig., 375 F. Supp. 2d 721 (N.D. Ill. 2005). The Slave Descendants case was particularly important because it was the first major reparations case in federal court in ten years. Previously, in the only opinion by an appellate court dealing with reparations, claims against the government were dismissed. See Cato v. United States, 70 F.3d 1103 (9th Cir. 1995). Slave Descendants took a different tack, seeking compensation from private rather than governmental actors. Both Cato and Slave Descendants are discussed in more detail infra.

6. See Brophy, Reparations Talk, supra note 1.

7. Cf. $i d$. at 83-86 (discussing the development of reparations discourse). 
the unique problems of causation and attenuation that arise in the reparations context.

Causation is a familiar concept to legal scholars. Tort liability requires a showing of proximate causation. ${ }^{8}$ Claimants must show not only conceptual "but-for" causation-that "but for" a party's actions, the harm would not have occurred-but must also establish legally actionable "proximate cause." 9 In reparations cases, the attenuated nature of the harm makes it difficult to show proximate cause. ${ }^{10}$

8. See, e.g., Richard W. Wright, Causation in Tort Law, 73 CAL. L. Rev. 1735, 1737-39 (1985); Guido Calabresi, Concerning Cause and the Law of Torts: An Essay for Harry Kalven, Jr., 43 U. CHI. L. REv. 69, 69-72 (1975).

9. See Elizabeth C. Price, Toward a Unified Theory of Products Liability: Reviting the Causative Concept of Legal Fault, 61 Tenn. L. Rev. 1277, 1347 (1994) (“'Cause-in-fact,' 'factual cause,' or 'but for' causation, as every first-year law student knows, is generally an indispensable requisite to recovery in tort. It is the first head of the two-headed hydra of causation. The other head ... is 'proximate' or 'legal' cause, a policy tool designed to cut off liability for acts perceived as too remote, attenuated, or mere conditions."); Kim Forde-Mazrui, Taking Conservatives Seriously: A Moral Justification for Affirmative Action and Reparations, 92 CAL. L. Rev. 683, 727 (2003) ("Actual causation is but a starting point for establishing responsibility, making the causal agent 'eligible' for responsibility."); W. PAGe KeEton eT al., Prosser and Keeton on the Law of Torts 264 (West 5th ed. 1984) ("As a practical matter, legal responsibility must be limited to those causes which are so closely connected with the result and of such significance that the law is justified in imposing liability."). Thus, the law generally treats as actionable those "consequences which follow in unbroken sequence, without an intervening efficient cause, from the original negligent act." See 57A AM. Jur. 2D Negligence $\S 491$ (2004). "For such consequences the original wrongdoer is responsible, even though he or she could not have foreseen the particular results which did follow or results of a similar nature." Id.; see also KEETON ET AL., supra, at 301-08 (discussing intervening causes); OSCAR S. GRAY, ThE LAW OF TORTS 86-87 (Aspen 2d ed. 1986) (discussing proximate cause).

10. In the words of one critic, reparations advocates point to an injury that is not "'fairly traceable' to slavery through a chain that contains no links of independent causation." Calvin Massey, Some Thoughts on the Law and Politics of Reparations for Slavery, 24 B.C. THIRD WORLD L.J. 157, 166 (2004) ("I am contending only that the nexus between slavery and the present forces that produce the sense of injustice felt by black Americans today is too attenuated to merit a judicial award of damages based on restitution."); see infra Part II (discussing attenuation in reparations literature). For other examples of the attenuation discussion in reparations literature, see, for example, James R. Hackney, Jr., Ideological Conflict, African American Reparations, Tort Causation and the Case for Social Welfare Transformation, 84 B.U. L. REv. 1193 (2004) (noting causation problems in reparations context); Art Alcausin Hall, There Is a Lot to Be Repaired Before We Get to Reparations: A Critique of the Underlying Issues of Race that Impact the Fate of African American Reparations, 2 ScHOLAR 1, 27-32 (2000) (noting recurrence of the attenuation defense); Eric J. Miller, Reconceiving Reparations: Multiple Strategies in the Reparations Debate, 24 B.C. THIRD WORLD L.J. 45, 52 (2004) (noting the problem of attenuation); Eric Posner \& Adrian Vermeule, Reparations for Slavery and Other Historical Injustices, 103 Colum. L. Rev. 689, 708 (2003) (noting difficulty in connecting past wrongs to present harm). 
Attenuation is diminished or failed causation. ${ }^{11}$ Attenuation is typically created by a conceptual separation between two actors or events or a dilution or weakening of the conceptual connection between the two. As such, attenuation severs theoretical "but-for" causation from legally actionable proximate cause.

This Article turns an analytical eye to attenuation arguments used in the reparations debate-defining and examining different types of attenuation arguments that arise in the literature. Attenuation arguments as used in the reparations debate come in three types, which this Article identifies and classifies as victim attenuation, wrongdoer attenuation, and act attenuation. Victim attenuation is found in the argument that modern Blacks ${ }^{12}$ have no direct connection to slaves; wrongdoer attenuation is the argument that modern Americans tend to lack specific individual connections to slave holders; and act attenuation articulates the idea that modern injury to Blacks is unrelated to the harms of slavery. ${ }^{13}$ After defining terms and examining how attenuation arguments are used in the slave reparations context, the Article then discusses concepts from mass torts jurisprudence that could apply to the reparations debate. ${ }^{14}$

11. "[T] he longer the interval between the protected activity and the adverse employment action, the more attenuated becomes the evidence of the requisite causation." Spadola v. N.Y. City Transit Auth., 242 F. Supp. 2d 284, 294 (S.D.N.Y. 2003). See generally 57 AM. Jur. 2D Negligence $\$ \S 465,491$ (1989 \& Supp. 2000) (discussing how temporal factors and an intervening circumstance affect remoteness and causation analysis).

12. Throughout this Article, I will use the term "Black" rather than "black" or "African-American." Cf. Kimberle W. Crenshaw, Race, Reform, and Retrenchment: Transformation and Legitimation in Antidiscrimination Law, 101 HARV. L. REv. 1331, 1332 n.2 (1988) ("I shall use 'African-American' and 'Black' interchangeably. When using 'Black,' I shall use an upper-case 'B' to reflect my view that Blacks, like Asians, Latinos, and other 'minorities,' constitute a specific cultural group and, as such, require denotation as a proper noun.").

13. See infra Part II.A (discussing victim, wrongdoer, and act attenuation).

14. Causation and attenuation concerns have thus far received little sustained treatment in the reparations literature. A number of scholars have discussed concepts of causation briefly. See, e.g., Brophy, Some Problems, supra note 1, at 519; Posner \& Vermeule, supra note 10 , at 739 . However, the only direct analysis of causation from the tort standpoint has been James Hackney's short essay, Ideological Conflict, African American Reparations, Tort Causation and the Case for Social Welfare Transformation. See Hackney, supra note 10.

Hackney's analysis is similar in some ways to the analysis in this Article and provides a useful jumping off point. Hackney suggests different types of causal problems, which are similar to the types of attenuation analyzed in this Article. This Article, however, differs from Hackney's essay in many respects. Its classificatory scheme identifies the problems as stemming from attenuation and classifies them in a way that aids the analysis. This Article also discusses how tort law has dealt with these types of attenuation and sets out a series of suggested applications that are beyond the treatment in Hackney's essay.

This Article also builds on the pioneering work of Al Brophy, who previously noted the conceptual problems of causation and discussed them briefly in his broad-ranging article dealing with many of the legal arguments relating to reparations. See Brophy, Some 
In the end, the Article seeks to set out a framework for analyzing attenuation and to work through some of the major legal attenuation problems. It will not address all possible attenuation concerns but will address some major legal concerns; it will also set forth a framework for analyzing these concerns so that reparations claims can move forward. A solution to the attenuation problem might allow reparations talk to become reparations reality.

\section{Background}

\section{A. Types of Reparations Claims}

Claims for slavery reparations encompass a number of different legal theories, but the two major strands are tort and unjust enrichment. ${ }^{15}$ The most straightforward type of claims are tort claims. Slaves suffered many deprivations that could potentially trigger tort liabil-

Problems, supra note 1, at 505 (noting problems of causation in reparations). Brophy's article is a very useful broad survey of the many arguments that arise in reparations, and their effects. While it is an invaluable roadmap to the theories of liability in the reparations context, it does not focus on the particulars of causation in the level of detail set out in this Article and does not suggest the use of mass tort tools to help solve the problem.

This Article is also limited in its own scope. This Article will primarily address attenuation in reparation cases brought for the harm of slavery. Other reparations cases, such as lawsuits brought for the Tulsa riots, present different questions of causation and will not be discussed in any depth herein. See Keith N. Hylton, A Framework for Reparations Claims, 24 B.C. THIRD WORLD L.J. 31, 43 (2004) [hereinafter Hylton, Framework], which states:

When thinking about reparations claims, one should avoid the mistake of viewing them as monolithic, having the same difficulties in terms of identification of plaintiffs, causation, and prescription of legal rights. In fact, reparations claims vary along many legal dimensions, creating a rich array in terms of their consistency with settled law.

Id. See generally Alfred L. Brophy, Reconstructing the Dreamland: The Tulsa Riot of 1921 (2002) (giving background of Tulsa riots). This Article focuses on individual reparations claims, rather than on claims that might be brought by African nations seeking compensation for the loss of citizens. Finally, it focuses on claims derived from the harm of slavery itself, rather than claims based on post-emancipation acts such as racism or segregation.

15. This is generally recognized in the literature. See, e.g., Brophy, Some Problems, supra note 1, at 516 ("As to substantive basis, the most commonly cited bases are unjust enrichment and tort.").

Other theories are possibilities. Some commentators have suggested bringing human rights claims. For example, in provocative language that evokes the possibility of a human rights claim, Randall Robinson suggests that slavery was "[a] massive crime against humanity ... an American holocaust." Should America PAY?, supra note 1, at 33. And in another article, this Author has argued that slave descendants could seek recompense under the takings clause for taken self-ownership. Wenger, supra note 1. Despite these and other intimations, the two dominant approaches in reparations thus far are tort and unjust enrichment. 
ity. ${ }^{16}$ They routinely suffered harms including physical injury, loss of property, lost wages, loss of liberty, loss of family relations, loss of consortium, and mental anguish. ${ }^{17}$ Their descendants suffer today from residual racism, a consequence of slavery. ${ }^{18}$

There are also some important conceptual obstacles to any tort claim arising from slavery. For one thing, it is unclear whether slave owners owed a legal duty to slaves. It is also unclear whether they owed any duty to slave descendants. ${ }^{19}$ Nevertheless, a colorable argument can be made that either slave owners indeed owed a duty to slaves or their descendants, or that they should have been aware that the regime of slavery was legally dubious in a way that they should not be surprised to be held to have owed a duty to slaves or their descendants. ${ }^{20}$ For purposes of this Article, in order to focus on causation issues, we will assume that slave owners owed a duty either to slaves or to their descendants and that tort compensability of slavery is not negated by its legality at the time. ${ }^{21}$

In addition to tort theories, reparations claims have been brought under unjust enrichment theories. Unjust enrichment claims differ from tort claims in significant ways. While a tort claim is a claim at law arising from a breach of duty and a negligent or intentional harm, an

16. "Against the proper defendants, the idea of some kind of legal action designed to punish and secure compensation seems not only sensible, but also compelling." Anthony J. Sebok, Two Concepts of Injustice in Restitution for Slavery, 84 B.U. L. Rev. 1405, 1417 (2004) [hereinafter Sebok, Two Concepts].

17. See Keith N. Hylton, Slavery and Tort Law, 84 B.U. L. Rev. 1209, 1213-37 (2004) [hereinafter Hylton, Slavery] (discussing types of harms arising from slavery); Sebok, Two Concepts, supra note 16, at 1417; see also Kevin Hopkins, Forgive U.S. Our Debts?, Righting the Wrongs of Slavery, 89 GEO. L.J. 2531, 2534 (2001) (“[T]he wrongs done to African slaves during slavery, such as the physical capture and exploitation of Africans for labor, the inhumane treatment and abuse of slaves by white slaveholders, and the psychological abuses in failing to acknowledge and respect African personhood, to name only a few, were horrible and unfathomable.").

18. See, e.g., Wenger, supra note 1, at 224-26.

19. If there was no duty owed to either slaves or to future generations (or to some other party harmed under slavery), then there is no tort claim. See KEETON ET AL., supra note 9, at 301-20 (noting need to establish duty). In addition, if the duty owed to a party is particularly weak, it could be viewed as affecting other aspects of tort liability, such as causation. See generally Brophy, Some Problems, supra note 1, at $516 \mathrm{nn} .84-85$ (discussing conceptual problems with tort liability for slavery).

20. Hylton, Slavery, supra note 17, at 1212 (arguing that slavery was a lawless regime, and that "[a]pplying today's law to [slavery] should be viewed as bringing law to a regime from which it had been entirely displaced ....").

21. Tort law routinely compensates victims of harm caused by acts that were legal when performed, such as use of asbestos or Agent Orange, or provision of tobacco or DES. See also Hylton, Slavery, supra note 17, at 1212 (suggesting that the legality of slavery undermines the legitimacy of the legal system of the time). 
unjust enrichment claim is a hybrid claim in law and equity and requires a claimant to show only that a defendant unjustly obtained some benefit from the claimant that should be refunded. ${ }^{22}$ The measure of damages is the amount of unjust gain. ${ }^{23}$ Unjust enrichment claims provide certain tactical advantages in mass compensation litigation and have been successfully used in Holocaust and tobacco cases. ${ }^{24}$ Unjust enrichment claims have been brought in the slave reparations context, though academics are divided as to whether they are appropriate in this area. ${ }^{25}$ Some scholars have suggested that economic loss should be treated as non-descendible. ${ }^{26}$ This view is contested, with others suggesting that economic loss claims ought to be

\section{According to Anthony J. Sebok:}

The minimum requirements for a claim of unjust enrichment based on quantum meruit are: (1) A benefit conferred upon the defendant by the plaintiff; (2) an appreciation or knowledge of the benefit by the defendant; and (3) the acceptance or retention by the defendant of the benefit under such circumstances as to make it inequitable for the defendant to retain the benefit without payment of its value.

Sebok, Two Concepts, supra note 16, at 1427; see also Anthony Sebok, Reparations, Unjust Enrichment, and the Importance of Knowing the Difference Between the Two, 58 N.Y.U. ANN. SuRv. AM. L. 651, 654-55 (2003) [hereinafter Sebok, Knowing the Difference] (further discussing unjust enrichment); Brophy, Some Problems, supra note 1, at 521 (discussing arguments in favor of unjust enrichment reparations compensation).

23. See Anthony Sebok, Prosaic Justice, 2002 Legal Afr. 51, 52 [hereinafter Sebok, Prosaic Justice]; Emily Sherwin, Reparations and Unjust Enrichment, 84 B.U. L. Rev. 1443, 1447-49 (2004).

24. Unjust enrichment claims are less susceptible to statute of limitations defenses. See Sebok, Knowing the Difference, supra note 22, at 653; see also Sebok, Two Concepts, supra note 16 , at 1418 (noting that states in the tobacco litigation used unjust enrichment claims, since these are less susceptible to affirmative defenses). They may have other tactical advantages. Sherwin, supra note 23 , at 1449-51.

Unjust enrichment was included in the Holocaust cases through a circuitous routethe case was originally a replevin claim, and restitution was later added as an additional effective tool. Sebok, Two Concepts, supra note 16, at 1407. The restitution claims ended up being central in the Holocaust settlement. See id.; see also Sebok, Prosaic Justice, supra note 23, at 52. Unjust enrichment claims, however, are uniquely susceptible to equitable defenses. Sebok, Knowing the Difference, supra note 22, at 655 . In addition, they may be less morally compelling than conventional tort claims. Id. at 657; Sebok, Prosaic Justice, supra note 23 , at 52-53.

25. Compare Sebok, Two Concepts, supra note 16, at 1440-42 (suggesting that restitution for deceased persons such as slaves is not conceptually coherent and should be avoided), and Sherwin, supra note 23, at 1454-65 (arguing that unjust enrichment reparations claims are inappropriate because they rely on resentment and retaliation), with Hanoch Dagan, Restitution and Slavery: On Incomplete Commodification, Intergenerational Justice, and Legal Transitions, 84 B.U. L. REv. 1139, 1158-63 (arguing that restitution claims are descendible and appropriate in the reparations context).

26. Sebok, Two Concepts, supra note 16, at 1431-41. 
viewed as descendible. ${ }^{27}$ In any event, it is seen as practically important; one commentator has argued that unjust enrichment is "the only viable strategy remaining" for reparations advocates. ${ }^{28}$ In practice, successful litigation of an unjust enrichment claim would result in defendants paying unjust enrichment damages based on whatever amount of unjust enrichment they received from their acts. Slave descendants would recover the amount of enrichment that the defendants gained through involvement in slave labor or the slave trade.

In addition to the divide between tort and unjust enrichment approaches, there is also a division in reparations between ancestor-based and descendant-based theories. That is, it is possible to bring a claim focused on the harms done to the initial slaves (ancestor-based theories) or claims focused on the harms that slave descendants continue to suffer today (descendant-based theories). Of course, any particular litigant may seek to raise both ancestor and descendant-based claims.

The two different focal points bring their own advantages and disadvantages. An ancestor-based approach will have no problem showing harm-it is undisputed that slaves were harmed, and a strong case can be made for restitution to them. ${ }^{29}$ Nevertheless, since no slaves are presently alive, an ancestor-based approach encounters difficulties on remedies: should a slave descendant receive remedies for harms done to an ancestor?

A descendant-based approach elides that difficulty but runs into the opposite problem. Descendants will not have a problem establishing that they are the proper recipient of a remedy-if they can first establish a harm done to them. But the descendant-based theory suffers from the difficult question of establishing harm-how are modern slave descendants harmed by slavery? Ultimately, each theory depends on the resolution of the same difficult questions of causation, such as how slaves can be connected to modern claimants.

\section{B. General Principles of Causation}

It is black letter law that a tort claimant must show causation in order to establish liability against a defendant. ${ }^{30}$ The idea of causa-

27. Dagan, supra note 25, at 1158-64. One way to elaborate on Dagan's theory is to suggest that unjust enrichment claims brought for property loss, rather than tort-like claims, could be viewed as more easily passed from one generation to the next.

28. Sebok, Prosaic Justice, supra note 23, at 52.

29. See Andrew Kull, Restitution in Favor of Former Slaves, 84 B.U. L. Rev. 1277 (2004) (discussing cases of restitution to slaves found to have been wrongfully enslaved).

30. See KeEton et Al., supra note 9, at 263-67. 
tion, however, is often difficult to apply in particular cases. Wellknown conceptual problems may complicate any attempt to assign liability for an act to a preceding "cause" 31 — while an infinite number of factors may be considered "but-for" or "factual" causes of a harm, ${ }^{32}$ only some of those will be considered legally actionable causes-those which the law deems "proximate." 33 The determination of legal causation depends in part on whether an initial event is necessary, sufficient, or both, in the causing of a second event. ${ }^{34}$

In the most simple causative scenario, an initial event is both necessary and sufficient to cause a second event. For example, David might run into Louise with his car, causing her leg to be broken. The causative event-David's collision with Louise-is both necessary and sufficient to cause Louise's broken leg.

When a causative event is either not necessary or not sufficient to create a second event, causation becomes more complicated. If an initial event is not necessary, causation is overdetermined. In the classic example, two negligently set fires merge, and a property is destroyed by the joint fire. ${ }^{35}$ Either fire on its own would have destroyed the property, and so neither fire taken individually was necessary to cause the end result. If Fire A had never been set, Fire B would still have led to the result.

31. Every effect has multiple causes. Wex S. Malone, Ruminations on Cause-In-Fact, 9 Stan. L. Rev. 60, 62 (1956); see also Wright, supra note 8, at 1737 (noting that there are innumerable causes for each injury); $i d$. at 1780-88 (discussing tort scholarship about multiple causes); Glen O. Robinson, Multiple Causation in Tort Law: Reflections on the DES Cases, 68 VA. L. Rev. 713, 713-14 (1982) (arguing that causation is vague, can be manipulated, it is more than a simple question of fact, and that actual cause involves policy questions just as proximate cause does) [hereinafter Robinson, DES cases].

32. H.L.A. Hart \& Tony Honore, Causation in the Law 10-11 (Clarendon Press 1967) (1959); KEETON ET AL., supra note 9, at 266 (“[M]any courts have derived a rule, commonly known as the 'but for' or 'sine qua non' rule, which may be stated as follows: The defendant's conduct is a cause of the event if the event would not have occurred but for that conduct; conversely, the defendant's conduct is not a cause of the event, if the event would have occurred without it."); GRAY, supra note 9, at 90-91 (discussing but-for cause).

33. KeETON ET AL., supra note 9, at 263 ("An essential element of the plaintiff's cause of action for negligence, or for that matter for any other tort, is that there be some reasonable connection between the act or omission of the defendant and the damage which the plaintiff has suffered. This connection usually is dealt with by the courts in terms of what is called 'proximate cause,' or 'legal cause.' "); see also GrAY, supra note 9, at 85-91 (discussing proximate and but-for cause); Calabresi, supra note 8, at 72-76 (discussing this difference).

34. See HART \& Honoré, supra note 32, at 10-20; KEeton ET AL., supra note 9, at 263-67.

35. HART \& Honoré, supra note 32 , at 10-15. 
In contrast, if an initial event is not sufficient to bring about a second event, we say that causation is underdetermined. ${ }^{36}$ Thus, in the well-known case of Palsgraf $v$. Long Island Railroad $\mathrm{Co}^{37}$ the initial event (negligent handling of a box) led to a chain of future events. The box was dropped (a second necessary condition); the box contained fireworks (a third necessary condition) that exploded; the explosion toppled a set of scales (a fourth necessary condition); and finally the plaintiff was harmed. ${ }^{38}$ We would say that dropping a box is normally not sufficient to cause such a chain of events. Causation was found to be underdetermined in Palsgraf, leading to a finding of no liability. ${ }^{39}$ Similarly, if a sailor falls off of a ship and drowns, and the ship did not have adequate safeguards, it may be impossible to know if the safety measures would have saved the sailor. ${ }^{40}$ The sailor may have been swept overboard despite the precautions; the cause of his death is underdetermined. ${ }^{41}$

Both underdetermined and overdetermined causation are commonly found in the mass tort context. A defendant's product may not be necessary to cause a particular harm, making individual cases overdetermined. Where the harm manifests in a physical disease that can have many causes, showing conventional causation can be difficult. ${ }^{42}$ As Margaret Berger notes, harms for which plaintiffs seek compensation may be "found in others who have not been exposed to the substance or product in question." 43 Thus, "it is impossible to tell whether any individual plaintiff's injury is attributable to the product or

36. See Aaron Twerski \& Anthony J. Sebok, Liability Without Cause? Further Ruminations on Cause-In-Fact as Applied to Handgun Liability, 32 CoNn. L. REv. 1379, 1380 (2000) ("[T] he problem was one of underdetermination. The reason we don't know if the defendant's breach of duty caused the injury is because we don't know whether the victim was in a position to benefit from the increase in safety that the duty was supposed to guarantee."); see also Malone, supra note 31, at 64-65 (stating that the process of determining causation is often "basically one of conjecture"). See generally Michael Dummett, Frege: Philosophy of LANGUAGE (1981) (discussing the conceptual idea of underdetermination).

37. 162 N.E. 99,100 (N.Y. 1928).

38. Id.

39. Id. at 101.

40. Malone, supra note 31 , at 76 .

41. Id.; Twerski \& Sebok, supra note 36 , at 1379-82.

42. See Margaret A. Berger, Eliminating General Causation: Notes Towards a New Theory of Justice and Toxic Torts, 97 Colum. L. REv. 2117, 2123 (1997) ("None of these categories of evidence is capable, however, of proving conclusively a cause and effect relationship .... Evidence of this kind is inherently subject to considerable uncertainty and inconclusiveness."); Steve Gold, Note, Causation in Toxic Torts: Burdens of Proof, Standards of Persuasion, and Statistical Evidence, 96 YALE L.J. 376, 380 (1986).

43. Berger, supra note 42 , at 2122. 
whether it would have manifested itself anyhow." 44 This difficulty results from the number of causes that can contribute to a disease; as another commentator notes, "Rarely is any particular toxic agent the exclusive source of a given disease. Insidious diseases generally have several sources, each of which may by itself be sufficient to bring about the condition." 45 Underdetermination is also a concern since a defendant's product may lead to disease only through interaction with other acts or circumstances. ${ }^{46}$ Finally, mass torts typically involve a large number of plaintiffs harmed by a defendant's product. Some of their cases may involve simple causation, while others may have underdetermined or overdetermined causative chains.

With this brief background in causation, we can now turn to the specific case of reparations for slavery.

\section{Three Types of Attenuation in Reparations}

In the reparations context, many different types of arguments are often raised to challenge the idea of causation. Such arguments use the language of attenuation to emphasize that whatever causal relationship exists between the defendant's act and the plaintiff's harm is insufficient to sustain a cause of action since the harm incurred is too remote from the defendant's act. These attenuation arguments can be divided up in a way that helps us analyze them. Some of these arguments impact the causation analysis directly, while others are less directly related.

Part II examines three major thematic strands of attenuation arguments that arise in discussions of reparations. Much of Part II is descriptive and sets out various attenuation arguments as they have been used by others. It is also classificatory, in that it will place specific statements into one or more categories. Section A will discuss act attenuation, Section B will discuss victim attenuation, and Section $\mathrm{C}$ will examine wrongdoer attenuation. These interrelated but distinct com-

44. Id.; see also Gold, supra note 42, at 376-77 ("Proving the cause of injuries that remain latent for years, are associated with diverse risk factors, and occur at background levels even without any apparent cause, is the 'central problem' for toxic tort plaintiffs.").

45. David Rosenberg, The Causal Connection in Mass Exposure Cases: A "Public Law" Vision of the Tort System, 97 HARv. L. Rev. 849, 856 (1984); see also JACK B. WEINSTEIN, INDIVIDual Justice in Mass TORT Litigation 148-55 (1995) (discussing this problem); Robinson, DES cases, supra note 31 , at 759 (stating that a deterministic causation approach that assumes a clean relation between an act and the injury is not useful in indeterminate cases which require probabilistic evidence).

46. See, e.g., Berger, supra note 42, at 2123-30; Robinson, DES cases, supra note 31 , at 759-60; Rosenberg, supra note 45, at 855-56. 
ponents correspond to a perceived lack of connection between deceased slaves and present claimants (victim attenuation), between slave beneficiaries (slave holders and governments) and modern citizens or governments (wrongdoer attenuation), and between harmful acts of slavery and any present injury (act attenuation). ${ }^{47}$ These thematic strands function as important analytical tools for understanding the complexity of causation arguments and the nuances of attenuation-based challenges.

\section{A. Act Attenuation}

The first type of attenuation argument that arises in reparations is act attenuation-the idea that there is no direct connection between

47. Some other writers have noted the presence of some of these general themes in reparations. See Brophy, Some Problems, supra note 1, at 505 ("There are, then, several distinct problems between connecting past and present. There are problems in connecting the past wrongdoers with their successors (who would be the present defendants); problems in connecting past victims with their successors (who would be the present plaintiffs); and connections between past wrongs and present claims."); see also id. at 502-03 ("The claims are hard to fit into a traditional framework for two reasons. First, the victims are making claims against people who are not themselves wrongdoers. Furthermore, that defendant class may not have any current benefit from the harm. In that case, there will be a claim asserted against a discrete group of innocent people. . . . Often the perpetrators cannot be identified with specificity or are no longer alive."); Hylton, Framework, supra note 14, at 39-40 (discussing different types of claims and distinguishing them based on whether injurers and victims are identifiable); Posner \& Vermeule, supra note 10 , at 698 ("Reparations claims thus involve three relationships: (1) the relationship between the original wrongdoer and the original victim; (2) the relationship between the original wrongdoer and the possible payer of reparations; and (3) the relationship between the original victim and the possible claimant or beneficiary of reparations. The claimant must show that each relationship is of the proper type."); id. at 699 ("Compensatory justice requires a relationship of identity between the wrongdoer and payer and a relationship of identity between the victim and claimant."); Alfreda Robinson, Corporate Social Responsibility and African American Reparations: Jubilee, 55 Rutgers L. REv. 309, 365 (2003) (noting that opponents of reparations focus on specific difficulties including "the absence of directly harmed individuals," "the absence of individual perpetrators," and "the lack of direct causation") [hereinafter Robinson, Corporate Responsibility]; Verdun, supra note 2, at 628-30 ("Opponents of reparations to African Americans argue that living whites have not injured living African Americans; the wrongs of slavery were committed by individuals who have been dead for years. African Americans living today were never slaves, and are not entitled to wages for slave labor performed over one hundred years ago.").

Little of the existing scholarship discusses the significance of these different variants of attenuation, or seeks to classify and analyze these divisions, as I do in this Article. The closest analogue is James Hackney's analysis in his recent essay. See Hackney, supra note 10, at 1195-97 (discussing "identification, boundary, and source" causation issues). However, Hackney's analysis, which is briefer than the discussion and analysis in this Article, differs from my analysis in several respects. Hackney's essay uses a preliminary discussion of some causation issues to frame an analysis that focuses on social welfare discussions. In contrast, this Article focuses on the causation concerns themselves, and how they could be addressed by using conceptual tools from the mass torts context. 
past wrongdoing and present harm. Act attenuation is not unique to reparations but is a common theme in much of tort litigation. For example, Palsgraf, with its unique chain of events leading to the ultimate injury, gives an example of act attenuation. ${ }^{48}$ Act attenuation may be created by overdetermined or underdetermined causation. Act attenuation is an attack on the move from conceptual but-for causation to legally actionable proximate cause. ${ }^{49}$

Act attenuation is also a common objection to slavery reparations. ${ }^{50}$ One critic notes that a "problematic consideration is causation, which invokes the question of whether the injury presently complained of was a foreseeable product of the defendant's conduct. ... [ [I] $t$ is necessary to wrestle with the issue of whether that past conduct has caused injury to a contemporary plaintiff." 51 This objection is easy to understand. It can be difficult, after all, to connect the harms of slavery to specific disadvantages of Blacks today. Indeed, it is not easy to characterize Blacks as a cohesive economic group at all. There are vast differences in wealth, status, and class among individual Blacks. ${ }^{52}$ Some individuals appear to have integrated smoothly into society, while others have not. ${ }^{53}$

The difficulty of unraveling potential contributing or ameliorating causes leads to act attenuation. Thus, a "lack of sufficient connection between past wrong and present claim" is an argument that Mari J. Matsuda calls one of the "standard doctrinal objections to repara-

48. Palsgraf v. Long Island R.R. Co., 162 N.E. 99 (N.Y. 1928).

49. See generally KEETON ET AL., supra note 9, at 266.

50. See, e.g., Birtker, supra note 1, at 9; Brophy, Some Problems, supra note 1, at 518-19. Attenuation is not a special or uniquely high hurdle to forestall reparations claims, though they may be unusually susceptible to this defense. Posner \& Vermeule, supra note 10 , at 711. Attenuation is a familiar bugbear for civil rights advocates. See Maria L. Marcus, Leaming Together: Justice Marshall's Desegregation Opinions, 61 Fordham L. REv. 69, 90-95 (1992) (noting Supreme Court use of attenuation to rule against desegregation claims).

There is certainly no agreement by reparations advocates that proximate cause is not satisfied. Brophy, Some Problems, supra note 1, at 523-25; Forde-Mazrui, supra note 9, at 728-33 (arguing that chain of proximate causation has not been broken by actions of slave descendants).

51. Massey, supra note 10 , at 162-63.

52. Matsuda, supra note 1 , at 375 . Of course, despite these differences, Blacks are overwhelmingly less well-off than whites. See generally Robert Westley, Many Billions Gone, Is It Time to Reconsider the Case for Black Reparations?, 40 B.C. L. Rev. 429, 471-72 (1998).

53. As Mari Matsuda notes, "Not all members of the victim group are similarly situated. Some are rich, some poor. Some feel betrayed, others do not. Some are easily identifiable as group members, others have weak claims to membership." Matsuda, supra note 1, at 375 . 
tions." ${ }^{54}$ Similarly, media and pundit statements discuss act attenuation. ${ }^{55} \mathrm{~A}$ number of critics suggest that shortcomings of Blacks, individually or as a group, are responsible for any present injury. ${ }^{56}$

Act attenuation affects reparations cases not only at trial or the motion stage, where it affects a showing of tort causation, but also has important indirect effects on claimants' very right to press a claim. Courts only allow claims by those who can show standing-that is, a direct connection between a wrongful act and a claimant's injury. ${ }^{57}$ Act attenuation is a factor in standing inquiry; as the Supreme Court has stated, a relevant question in deciding standing is, "Is the line of causation between the illegal conduct and injury too attenuated?" 58

Act attenuation is a normal obstacle that arises in many cases, not just those involving reparations. Many claimants bring cases where causation is either overdetermined or underdetermined. In particular, those kinds of issues often arise in mass compensation cases where a connection between initial acts and resulting harms may not always be clear.

Some conceptual tools exist to deal with the problem of act attenuation. For example, unjust enrichment claims may elude act attenuation because unjust enrichment depends only on a showing that a defendant was unjustly enriched. ${ }^{59}$ In addition, some scholars suggest that courts are likely to overlook act attenuation concerns in certain

54. Id. at 385. Matsuda's other standard objections are "factual objections and excuse or justification for illegal acts[;] difficult identification of perpetrator and victim groups; [and] difficulty of calculation of damages." Id. at 373-74; see also id. at 374 ("The problem of specific identification of wrongdoers and victims is a common objection to reparations.").

55. Horowitz writes that reparations is "based on the unfounded claim that all African-American descendants of slaves suffer from the economic consequences of slavery and discrimination" and that "[n]o evidence-based attempt has been made to prove that living individuals have been adversely affected by a slave system that was ended over 150 years ago." David Horowitz, Ten Reasons Why Reparations for Blacks Is a Bad Idea for Blacks-and Racist Too, Front Page, Jan. 3, 2001, at 6, available at http://www.frontpagemag.com/Articles/ReadArticle.asp?ID=1153.

56. See Forde-Mazrui, supra note 9, at 728-33 (discussing these arguments); see also Hylton, Framework, supra note 14, at 35-37 (discussing differences in Black and white family structure).

57. See Matsuda, supra note 1, at 380-81 ("The linkage of victims and perpetrators for acts occurring in the immediate past is another trait of standard legal claims."); see also Brophy, Some Problems, supra note 1, at 505 ("Closely related to the difficulty of identification of victims and wrongdoers is the requirement that there be a close connection between past wrong and present claim."); Verdun, supra note 2, at 624 (noting this requirement in affirmative action). This is a common theme in tort law. See, e.g., FED. R. Crv. P. 23 (setting out commonality requirement in class action lawsuits).

58. Allen v. Wright, 468 U.S. 737, 752 (1984).

59. See Sebok, Two Concepts, supra note 16, at 1416-17. 
cases, such as those involving personal injuries. ${ }^{60}$ Nevertheless, the general route for overcoming act attenuation is a factual one, and claimants generally overcome the problem by showing evidence of causal links.

Act attenuation is an important theme in any discussion of reparations. In addition to the standard act attenuation concerns that arise in reparations, intergenerational mass harm claims such as slave reparations involve two more specialized variants of the lack of causation argument which this Article addresses below.

\section{B. Victim Attenuation}

The first of the two more specialized concerns is what this Article calls victim attenuation. Victim attenuation is the idea that modern claimants are insufficiently linked to the original harmed parties. This lack of connection creates victim attenuation, a concern that is typically present only in intergenerational claims. Victim attenuation concerns arise not only in slavery reparations cases but in others that seek compensation for intergenerational harms, including cases involving harms to Native Americans, Holocaust victims, and Japanese internees. ${ }^{61}$

In the slavery context, victim attenuation is manifested in the argument that Blacks today are not sufficiently linked to slaves and are thus undeserving of any recompense for slavery. ${ }^{62}$ The basic idea underlying this concern is intuitive. Blacks living today were not directly subject to the harms of slavery. ${ }^{63}$ Many Blacks may be slave descendants, but many others are more recent arrivals who lack that connec-

60. Id. at 1439-41.

61. See Matsuda, supra note 1, at 364-68, 381-85; William Bradford, Beyond Reparations, 66 Oно Sт. L.J. 1, 52-60 (2005).

62. A related concern is that slave descendants today would not exist but for slavery and therefore are not entitled to recompense. See, e.g., Stephen Kershnar, The InheritanceBased Claim to Reparations, 8 Legal TheORY 243, 247-51 (2002).

63. "Opponents also argue that African Americans today were never slaves and did not directly experience the injustices of slavery and its effects and thus are not entitled to any form of reparations." Hall, supra note 10, at 30; see also Brophy, Some Problems, supra note 1, at 518-20; Miller, supra note 10, at 52; Horowitz, supra note 55. 
tion as well. ${ }^{64}$ Present claimants are not original victims and may have a relatively low proportion of descent. ${ }^{65}$

This concern appears in the literature on reparations. Stephen Kershnar argues that modern Blacks have only "token" rights of reparations because they are not sufficiently connected to slaves. ${ }^{66}$ Keith Hylton suggests that reparations claims must be treated as derivative claims under tort law-that is, claims that depend on the wrong done to another party rather than any harm done to the party bringing suit-which means that as a practical matter they will most likely fail. ${ }^{67}$ Al Brophy notes that "[f] ormulating a legal claim ... involves linking past victims with people who are making a claim in the present-or what one might call present victims of past discrimination."68 Media critics of reparations for slavery also emphasize victim attenuation. ${ }^{69}$

Victim attenuation concerns have been paramount in judicial decisions on reparations. Victim attenuation directly affects the legal analysis of a claimant's standing. For example, the Ninth Circuit Court of Appeals, in Cato $v$. United States, ${ }^{70}$ dismissed reparations claims brought against the government, stating that:

Cato proceeds on a generalized, class-based grievance; she neither alleges, nor suggests that she might claim, any conduct on the part of any specific official or as a result of any specific program that has run afoul of a constitutional or statutory right and caused her a discrete injury. Without a concrete, personal injury that is not ab-

64. See Brophy, Some Problems, supra note 1, at 519; Graham Hughes, Reparations for Blacks?, 43 N.Y.U. L. REv. 1063, 1064 (1968) (noting difficulties in identifying plaintiffs); Posner \& Vermeule, supra note 10, at 739; see also Linda Chavez, Promoting Racial Harmony, in The Afrirmative Action Debate 314, 314-22 (George E. Curry ed., 1996) (noting victim attenuation concerns relating to affirmative action); Posner \& Vermeule, supra note 10 , at 712 (discussing victim attenuation in affirmative action); Verdun, supra note 2, at 623 (same).

65. See Hopkins, supra note 17, at 2542-48 (discussing different levels of slave descent among reparations claimants).

66. Kershnar, supra note 62, at 251-58; see also Janna Thompson, Historical Injustice and Reparation: Justifying Claims of Descendants, 112 ETHICs 114, 116-21 (2001) (suggesting that the passage of time precludes reparations).

67. Hylton, Slavery, supra note 17 , at 1238-45.

68. Brophy, Some Problems, supra note 1, at 504.

69. For example, one critic argues that "it is obscene to think of this modern generation of black Americans profiting from the blood money drawn nearly 140 years ago from the exploitation of slaves." Juan Williams, Slavery Isn't the Issue, WALl ST. J., Apr. 14, 2002, at A26; see also Adolph Reed, On Reparations, Progressrve, Dec. 2000, 15, 16-17 (noting difficulty of connecting modern victims with slave ancestors); Merida, supra note 2, at C-01. Merida notes that "[o]pponents say there is no precedent for paying people who are dead, that reparations are usually awarded to survivors." Merida, supra note 2, at C-8.

70. 70 F.3d 1103 (9th Cir. 1995). 
stract and that is fairly traceable to the government conduct that she challenges as unconstitutional, Cato lacks standing. ${ }^{71}$

Similarly, the district court in the recent In re African-American Slave Descendants Litigation ${ }^{72}$ decision dismissed a number of consolidated claims in related cases brought against corporations. ${ }^{73}$ The court wrote:

Plaintiffs' alleged injury is derivative of the injury inflicted upon enslaved African-Americans over a century ago .... This is insufficient to establish standing, and contrary to centuries of well-settled legal principles requiring that a litigant demonstrate a personal stake in an alleged dispute ... . Plaintiffs cannot establish a personal injury sufficient to confer standing by merely alleging some genealogical relationship to African-Americans held in slavery over one-hundred, two-hundred, or three-hundred years ago. ${ }^{74}$

Plaintiffs sought to establish standing by arguing that they were slave descendants and claiming that, as the rightful heirs of their ancestors' assets, they suffered injury because their ancestors were not compensated for their labor. ${ }^{75}$ The court disagreed: "Plaintiffs' claim to the economic wealth of their ancestors' labor is conjectural. While most would like to assume that they will be the beneficiaries of their ancestors' wealth upon their demise, this is a mere assumption."76 In addition, the court ruled that the plaintiffs did not meet the requirements for third party standing: "Plaintiffs have not alleged a legally sufficient relation to their ancestors. All that Plaintiffs allege is a gene-

71. Id. at 1109. The court elaborated, "she does not trace the presence of discrimination and its harm to the United States rather than to other persons or institutions. Accordingly, Cato lacks standing to bring a suit setting forth the claims she suggests." Id. at 1110 .

72. 375 F. Supp. 2d 721 (N.D. Ill. 2005).

73. Id. That consolidated case proceeded under a different theory than Cato; it was brought not against the government but against corporations whose predecessor entities had benefited from slavery. Despite this difference, the issue of standing again proved decisive. The court initially dismissed claims in January 2004, giving leave to replead. See In re African-Am. Slave Descendants Litig., 304 F. Supp. 2d 1027 (N.D. Ill. 2004). In July 2005, the amended complaint was dismissed, in a substantially similar opinion. Slave Descendants Litig., 375 F. Supp. 2d at 721; see Anthony Sebok, The Lawsuit Brought by African-Americans Seeking Compensation from Corporations for the Wrongs of Slavery: Why the Opinion Dismissing the Suit Is Unpersuasive, Findlaw, Aug. 8, 2005, http://writ.news.findlaw.com/sebok/20050808. $\mathrm{html}$ [hereinafter Sebok, The Lawsuit] (noting similarity between the 2004 decision dismissing the original complaint and the 2005 decision dismissing the amended complaint).

The case was dismissed in part because of standing and attenuation issues, and in part because of the statute of limitations. Slave Descendants Litig., 375 F. Supp. $2 d$ at 770-80 (discussing statutes of limitation); $i d$. at 775-80 (discussing exceptions to the statute of limitations). See generally Robinson, Comporate Responsibility, supra note 47, at 366-68 (discussing statutes of limitations); Wenger, supra note 1, at 244-48 (same).

74. Slave Descendants Litig., 375 F. Supp. 2d at 748, 752.

75. Id. at 748.

76. Id. 
alogical relationship, and more is required under the law in order to confer third-party standing." 77

The difference between victim and act attenuation is subtle. While act attenuation is an assertion that a claimant has suffered no legally cognizable harm, victim attenuation is an assertion that the claimant is a person who should not bring a claim at all. In the context of descendant-based reparations suits, victim attenuation asserts that modern claimants are insufficiently linked to harmed parties, thus relying on act attenuation-the lack of a connection between a tort inflicted on a slave and any perceived present day harm. In the context of slave-based reparations, victim attenuation is not dependent on act attenuation but rather on the intergenerational gap itself and on the idea that modern claimants are not good representatives of slaves, who may have themselves once had colorable claims. Thus, concerns of victim and act attenuation are interrelated. Victim attenuation problems of standing exist because courts are unsure that current claimants can show they have been harmed. The same perceived inability to show harm would inevitably create act attenuation concerns at any trial. Nevertheless, a weaker connection between victims and harm may satisfy the victim attenuation standing concerns, while a stronger connection might eventually need to be shown to establish causation at trial.

Victim attenuation defenses potentially apply to both tort and unjust enrichment claims. Victim attenuation has arisen on both sides of the Slave Descendants litigation, for example. ${ }^{78}$ And both types of claims have foundered in court due at least in part to victim attenuation. ${ }^{79}$ Conceptually, to the extent that victim attenuation is an outgrowth, in part, of act attenuation, then unjust enrichment claimssome of which are less subject to act attenuation-may also be less susceptible to victim attenuation defenses.

\section{Wrongdoer Attenuation}

The third type of attenuation argument, wrongdoer attenuation, exists because present-day citizens and governments may not be closely connected to slave owners, suggesting that perhaps they should

77. Id. at 753. As the court noted, the requirement is that the party asserting third party standing show some injury in fact, and that that party also show that prudential considerations weigh in its favor. $I d$. at 752-53.

78. Id. at 752; see supra note 73 and accompanying text.

79. See supra note 73 and accompanying text. 
not be required to pay for harms caused by slavery. ${ }^{80}$ Many modern non-Blacks are not descendants of slave owners and have no apparent direct connections to them. ${ }^{81}$ All living descendants are a generation or more removed from slave owners. ${ }^{82}$ In addition, it is likely that most or all slave owner descendants have at least some ancestors that were nonslaveholders - and many are mixed descendants who have ancestry traceable both to slaveowners and to slaves themselves. ${ }^{83}$ All

80. See Brophy, Some Problems, supra note 1, at 519 ("The people who perpetrated the crimes of slavery are gone and their estates are (mostly) distributed. A few corporations survive and some of the money made from slavery is traceable to currently existing bank accounts. However, there are significant problems in imposing the liability of past generations of private actors on the current generation."); see also Matsuda, supra note 1, at 375 ("[O]f those taxpayers who must pay the reparations, some are direct descendants of perpetrators while others are merely guilty by association. Under a reparations doctrine, the working class. whites whose ancestors never harbored any prejudice or ill-will toward the victim group are taxed equally with the perpetrators' direct descendants for the sins of the past."); Posner \& Vermeule, supra note 10, at 736 ("Reparations are rarely paid by the original wrongdoers, that is, the individuals who performed the wrongful acts, whether or not on behalf of a state or corporate body. Substantive moral considerations must explain why nonwrongdoers-usually taxpayers or shareholders-should pay reparations; when these considerations fail, prudential considerations must be invoked."); Hall, supra note 10, at 30 ("White America today attempts to distance itself from both the 'sins of slavery' and of its forefathers, in an effort to deny responsibility for the past and present problems associated with race. Opponents of African American reparations contend that slavery and past injustices by White Americans were not conducted by individuals living today, but rather by individuals long dead.").

81. This is recognized in the reparations literature. See, e.g., Brophy, Some Problems, supra note 1 , at 519; Miller, supra note 10 , at 52; Verdun, supra note 2 , at $629-30$. And many modern Americans may not feel any sort of link to slave owners. However, based on casual observation, there seems to be at least some degree of connection that many white southerners feel for former slaveholders. This can be seen, for instance, in the detailed civil war role-playing activities; the continued prevalence of statues of confederate generals; the politically popular use of the confederate flag; and the resurgence of historical societies such as the Daughters of the Confederacy. Reparations opponents may be more connected to the past, and in particular to the slave-owning past, than they tend to admit in discussions about liability. See Jason Zengerle, Lost Cause, New Republic, Aug. 2, 2004, 14 (discussing popularity of Confederate reenactment and historical groups); see also Carter Davis, Race and Reparations, City Mag. (Tuscaloosa, Ala.), Apr. 24, 2004, at 5, available at http://www.al.com/printer/printer.ssf?/base/news/1082801701197890.xml (last visited Nov. 27, 2005).

82. Sebok, Two Concepts, supra note 16, at 1419-20.

83. See Posner \& Vermeule, supra note 10, at 740 . According to these authors:

The more difficult problem exists when the wrongdoing occurs on a large scale, and the wrongdoers and victims miscegenate, or their descendants miscegenate. A descendant of a victim might therefore also be the descendant of a wrongdoer. With sufficient mixing, reparations become pointless. It makes no sense for a person to pay reparations from one pocket to the other. Even with more limited mixing, one must grapple with the question whether to treat people differently on the basis of how many ancestors belong to the class of victims and how many belong to the class of wrongdoers. 
of this serves to greatly complicate the task of apportioning blame to living defendants. Thus, Vincene Verdun sums up the concepts underlying wrongdoer attenuation as follows:

From the dominant perspective, it would be patently unfair to make all white people or society pay for slavery because that would necessarily include people who did not participate in the wrong. These people include whites who are descendants of abolitionists and non-slaveholders, and immigrants, or descendants of immigrants, who came to this country after slavery was abolished; post slavery immigrants cannot be connected with a wrong associated with slavery. 84

Wrongdoer attenuation undercuts the moral force of reparations arguments, which are often presented as a demand for justice. ${ }^{85}$ Wrongdoer attenuation arguments may take the form of statistics, such as noting the number of people who have arrived in the country since 1865, the percentage of the populaze descending from post-bellum immigrants, and so forth. ${ }^{86}$

While victim attenuation may evoke the possibility of an unjustified windfall, wrongdoer attenuation brings to mind the image of an unjustified penalty. ${ }^{87}$ This is a strongly negative image to overcome in a society that places high value, at least rhetorically, on the protection

Id.

84. Verdun, supra note 2, at 630; see also The Conversation, WASH. POST, July 23, 2000, at F4 ("As a white woman, I am tired of being blamed for slavery because-and only because-I am white, when the fact of the matter is I am descended from Irish and German immigrants who didn't arrive on Ellis Island until well after the Civil War.") (statement of Peggy Sakagawa); Massey, supra note 10, at 162. Brophy notes that legal liability "requires linking past perpetrators with people who currently exist." Brophy, Some Problems, supra note 1 , at 504 .

85. Reparations advocates often use the language of culpability in reparations literature, though there has been some recent movement towards a less confrontational tone. See Miller, supra note 10, at 49-52 (arguing that reparations advocates have created problems by being unnecessarily confrontational); see also Brophy, Some Problems, supra note 1 , at $519 \mathrm{n.94}$ ("My point is that in talking about reparations for slavery and Jim Crow, one must be careful in talking about claims of victims against perpetrators, when many of the people against whom claims are being asserted are not perpetrators."); Alfred Brophy, Taking Reparations Seriously 16 (n.d.) (unpublished manuscript on file with author) ("For many reparationists, the focus is upon past harm as a way of arguing for reparations. Among others there seems to be little interest in reconciliation. But those voices are not the leaders in the field. They do not represent the most thoughtful reparationists."). Id. at 16. See generally Lee A. Harris, Political Autonomy as a Form of Reparations, 29 S.U. L. REv. 25 (2001); Lee A. Harris, "Reparations" as a Dirty Word: The Norm Against Slavery Reparations, 33 U. MEM. L. REv. 409 (2003).

86. See Horowitz, supra note 55, at 3-4.

87. See Jeremy Waldron, Superseding Historic Injustice, 103 ErHIcs 4, $26-27$ (1992) (noting these concerns). In addition, reparations opponents sometimes suggest that past acts, such as the Civil War, constitute sufficient payments for slavery. See, e.g., Posner \& Vermeule, supra note 10, at 730-31 (noting this argument); Horowitz, supra note 55, at 9. 
of the innocent. ${ }^{88}$ As Eric Posner and Adrian Vermeule note, "[a] strong tradition in the United States holds that individuals are not blameworthy for acts over which they have no control." ${ }^{99}$ Group sanctions are an exception. ${ }^{90}$

Wrongdoer attenuation has played a part in derailing proposed reparations legislation. Representative Henry Hyde, then-chair of the House Judiciary Committee, argued:

The notion of collective guilt for what people did [200-plus] years ago, that this generation should pay a debt for that generation, is an idea whose time has gone. I never owned a slave. I never oppressed anybody. I don't know that I should have to pay for someone who did [own slaves] generations before I was born. ${ }^{91}$

The political wrongdoer attenuation argument is couched in the moral language of wrong and right, rather than in legal language. ${ }^{92}$ Similar moral-inflected arguments are used by many prominent media critics of reparations. ${ }^{93}$

88. Verdun, supra note 2, at 620-22.

89. Brophy, Some Problems, supra note 1, at 548 (noting that American law typically ties legal liability to moral culpability); Daryl Levinson, Collective Sanctions, 56 STaN. L. Rev. 345, 347-48 (2003); Posner \& Vermeule, supra note 10, at 699.

90. In instances where group sanctions are tolerated, it is often as a form of deterrence, see Levinson, supra note 89 , at $348-49$, and such consequentialist justification would not apply to the case of reparations for slavery. See Massey, supra note 10, at 165 (noting that reparations have no deterrent value); see also Levinson, supra note 89 , at 347-48 (noting that Blacks have been subjected to collective sanctions in the past).

91. See Merida, supra note 2, at C-8; see also 136 Cong. Rec. S1312-03 (Feb. 21, 1990) (statement of Sen. Bumpers) (stating that "I am a son of the South. But I never owned a slave. My father never owned a slave" in arguing that modern Turkey should not be blamed for the Armenian genocide).

92. See Eric Yamamoto, Racial Reparations: Japanese American Redress and African American Claims, 40 B.C. L. REv. 477, 496-97 (1998) (discussing the political component of reparations arguments).

93. For example, Armstrong Williams criticizes the reparations movement for "seek[ing] to penalize our current government for what white slaveholders did centuries ago." Armstrong Williams, Presumed Victims, in Should America PaY?, supra note 1, at 167; see also id. at 170 (noting conceptual difficulty in assessing reparations against post-bellum immigrants). John McWhorter argues that some "obvious retorts" to the idea of reparations include "that many whites in America today arrived after emancipation [and] that many whites owned no slaves." John McWhorter, Against Reparations, in Should AmericA PAY?, supra note 1, at 191. David Horowitz has stated that reparations are inappropriate because "[o]nly a tiny minority of white Americans ever owned slaves" and "most [modern] Americans have no connection (direct or indirect) to slavery," among other reasons. Horowitz, supra note 55, at 1 . This article was widely distributed and received nationwide attention. See Brophy, Cultural War, supra note 3, at 1201. Michelle Malkin writes that reparations advocates seek payments from "the U.S. government, which means American taxpayers, which means tens of millions of people who had nothing remotely whatsoever to do with inflicting such injustice on anyone." Michelle Malkin, Get Out Your Reparations Calcula- 
Like victim attenuation, wrongdoer attenuation is not strictly a causation argument. Rather, it is an attack on the identity of the party against whom a claim is made. And like victim attenuation, it may be used in tandem with more traditional act attenuation arguments. Unlike victim attenuation, however, it is not limited to cases of intergenerational harm. "You got the wrong guy, judge," is a standard line of defense in many cases. And wrongdoer attenuation intersects with other kinds of attenuation, including act attenuation, in various ways. ${ }^{94}$

The strength of wrongdoer attenuation arguments will vary with a number of factors, primarily the identity of the party against whom a claim is asserted. Thus, this line of defense can be partially avoided through smart lawyering. Many reparations claims are brought against corporations, and these corporate entities may in fact be the same legal entity as that which originally harmed slaves. ${ }^{95}$ Because this step avoids wrongdoer attenuation, many reparations cases involve such long-lived entities. ${ }^{96}$ But that move, while lessening wrongdoer attenuation, can increase act attenuation, since the particular corporate en-

tor, TownHall.com, Aug. 15, 2002, available at http://www.townhall.com/columnists/ michellemalkin/mm20020815.shtml.

Other, less oppositional voices have also wondered about these concerns. Kevin Merida, a relatively sympathetic Washington Post reporter, frames the potential issue as: "Why should American taxpayers who never owned slaves pay for the sins of ancestors they don't even know? And what about those whose ancestors arrived here long after slavery ended?" Merida, supra note 2, at C-01.

94. One strain of wrongdoer attenuation argument is similar to the idea of over-determination. That is, modern parties can assert the wrongdoer attenuation argument that "[e]ven if my ancestor had decided to pay his slaves, the generalized harm to slave descendants would have taken place anyway."

This is an overdetermination argument, similar to saying that "since a hundred other people also poisoned the well, my own act of poisoning the well should not be viewed as causative of decedent's death." Thus, it is similar to the legal doctrine of substantial factor (that is, that a defendant is not liable unless her acts were a substantial factor in causing a harm). See infra Part IV.B.4 (discussing substantial factor). This kind of argument, while internally consistent, lacks the moral force of most wrongdoer attenuation arguments.

95. See infra note 211 and accompanying text.

96. There are conceptual questions about the validity of corporate punishment over time, since the burden falls on shareholders who were not owners of the corporation at the time the wrong occurred. See generally John C. Coffee, No Soul to Damn: No Body to Kick: An Unscandalized Inquiry into the Problem of Corporate Punishment, 79 MicH. L. Rev. 386 (1981) (discussing theoretical problems with punishing corporate entities); Jennifer Arlen \& William Carney, Vicarious Liability for Fraud Based on Securities Markets: Theory and Evidence, 1992 U. ILL. L. REv. 691, 699-702 (1992) (noting that economic loss for securities often falls on innocent shareholders). 
tity against whom the suit is brought may be removed from direct participation in harmful acts. ${ }^{97}$

Like victim attenuation, wrongdoer attenuation may be a less compelling defense against claims of unjust enrichment. This is because unjust enrichment claims are not based on the guilt of a particular defendant, only on a showing that he has been enriched. Despite this theoretical advantage, wrongdoer attenuation concerns were voiced by the Slave Descendants court as it dismissed reparations claims, noting that '[ $\mathrm{t}]$ he allegations of Plaintiffs' [complaint] do not link these Defendants to the alleged harm"98 and that the "[complaint] is devoid of any allegations that connect the specifically named Defendants or their predecessors and any of the Plaintiffs or their ancestors." 99

\section{Recap}

These three types of attenuation are used, often together, to suggest that reparations for slavery would not be appropriate. These critiques are not unique to the case of Black slavery reparations, and similar arguments apply in most or all reparations-type actions. ${ }^{100}$

The problem of attenuation arises repeatedly in the literature. Many commentators suggest that attenuation fatally undercuts the case for reparations. Such an assessment reflects judicial reality at present. In Slave Descendants, the court based parts of its opinion on all three types of attenuation. It mentioned wrongdoer attenuation" $[\mathrm{t}]$ he allegations of Plaintiffs' Complaint do not link these Defendants to the alleged harm"101 — and act attenuation-"Plaintiffs' Complaint is devoid of any allegations that any specific conduct of the Defendants was a cause of the continuing injuries of which Plaintiffs com-

97. There are exceptions to this general trend. For example, Holocaust litigants bringing suit against Ford Motor Company for its use of slave labor avoided both wrongdoer attenuation - the company was the same entity - and act attenuation, since the link between the act and the harm was clear. See generally Michael J. Bazyler, Nuremberg in America: Litigating the Holocaust in United States Courts, 34 U. RuCH. L. Rev. 1, 204-06 (2000) (discussing Ford litigation).

98. In re African-Am. Slave Descendants Litig., 375 F. Supp. 2d 721, 749 (N.D. Ill. 2005).

99. Id. at 740 .

100. See Matsuda, supra note 1 , at 372 (discussing attenuation defense in connection with reparations claims by Native Hawaiians); see also Posner \& Vermeule, supra note 10, at 699-711 (noting these types of objections to reparations generally).

101. Slave Descendants Litig., 375 F. Supp. $2 d$ at 749 (emphasis added). The court also wrote that the "[Complaint] is devoid of any allegations that connect the specifically named Defendants or their predecessors and any of the Plaintiffs or their ancestors." Id. at 740 . 
plain." 102 In particular, the Slave Descendants court, like the Cato court, focused on victim attenuation. ${ }^{103}$ Thus, the problems of victim, wrongdoer, and act attenuation certainly have been decisive in derailing reparations suits in court. ${ }^{104}$

\section{Preclusive Effects of Act, Victim, and Wrongdoer Attenuation in the Reparations Suits}

The presence of all three kinds of attenuation creates a particularly difficult hurdle for those seeking reparations. Attenuation concerns operate in legal and moral arenas to create doubts about the viability of any judicial or legislative progress towards a reparations settlement. ${ }^{105}$

\section{Id. at 750 .}

103. Id. at 752; see also In re African-Am. Slave Descendants Litig., 304 F. Supp. 2d 1027, 1067-68 (N.D. Ill. 2004) ("Plaintiffs' Complaint fails to connect any alleged injury of any one of the Plaintiffs or their ancestors to alleged conduct by any one of the Defendants or their predecessors. ... [T] he allegations in a complaint must be those relating to the plaintiff, not those of someone else.").

104. Other reparations cases in the courts have largely followed the reasoning of Cato without further discussion. See Bell v. United States, No. Civ. A. 301CV0338D, $2001 \mathrm{WL}$ 1041792 , at *2 (N.D. Tex. Aug. 31, 2001) (citing Cato in holding that plaintiff lacked standing); Bey v. United States Dep't of Justice, No. 95 CIV 10401, 1996 WL 413684, at *1 (S.D.N.Y. July 24, 1996) (same); Langley v. United States, No. C 95-4227, 1995 WL 714378, at $* 2$ (N.D. Cal. Nov. 30, 1995) (same); see also Himiya v. United States, No. 94 C 4065, 1994 WL 376850 , at *2 (N.D. Ill. July 15, 1994) (citing Cato in dismissing on sovereign immunity grounds).

105. Attenuation concerns are manifested in two different spheres. First, attenuation comes up in the moral sphere, with concerns that it is somehow wrong for reparations to be paid by those who are not connected to slavery. Cf. Forde-Mazrui, supra note 9 , at 685 (discussing moral arguments about reparations and affirmative action). Second, attenuation arises in the legal sphere, with objections that reparations cannot, for legal reasons, be paid to plaintiffs who lack standing or a more direct connection to the slaves who were harmed. See, e.g., supra Parts II.A-D (discussing the legal effects of attenuation).

These are opposite sides of the same coin. Massey, supra note 10, at 157 ("When grappling with providing reparations for slavery, two distinct categories of issues emerge: legal and political."). And just as the idea of reparations is based on a joint legal and moral argument, attenuation provides a joint legal and moral counter-argument. See Miller, supra note 10 , at $50-51$ which states:

Reparations, on this account, involves a demand for restoration of the ill-gotten gains of slavery to the group that was wronged. In so doing, it suggests both a legal strategy and an emotionally compelling moral argument. The legal strategy requires us to identify the various ways that blacks were harmed by whites who profited from slavery and then to sue for the repayment of those profits either to individuals or into some central fund for more general disbursement. The moral argument asserts that whites as a group were, and continue to be, responsible for the ills of the African American community. It is the power and simplicity of that moral claim that makes reparations at once so compelling an argument and so difficult for the vast majority of whites to endorse. 
It is often suggested in the reparations literature that successful resolution of slave reparations litigation may be a natural extension of other successful mass litigation, such as restitution to Holocaust victims or Japanese internees. ${ }^{106}$ In particular, the Holocaust victim cases did not involve the level of victim attenuation present in slave reparations. As Bert Neuborne, who helped lead the Holocaust restitution effort, writes, " $[t]$ he Holocaust cases dealt with a first-generation effort" to return "identifiable property from the unjustly enriched holder of the property to its true owner or a close relative." 107 The settlement provided limited recovery for heirs of very recently deceased class members, but nothing nearly on the level that slave reparations would require. ${ }^{108}$ The Holocaust litigation also avoided wrongdoer attenuation by focusing on existing governments and corporate entities. ${ }^{109}$ Thus, the litigation arguably only suffered from one type of attenuation, act attenuation.

Neuborne notes this difference, writing that largely due to attenuation problems, " $[t]$ he lines of identity have become so blurred" in slave reparations that "today's remedy may be more political than legal." 110 That assessment alone does not mean that reparations litigation is fruitless. The reparations movement, like the Holocaust compensation movement before it, is composed of "an untidy mixture of law, politics and raw emotion."111 In the Holocaust cases, legal claims did not prevail qua legal claims, but rather allowed advocates to

Id.; of. Yamamoto, supra note 92, at 518 ("Those seeking reparations need to draw on the moral force of their claims (and not frame it legally out of existence) while simultaneously radically recasting reparations in a way that both materially benefits those harmed and generally furthers some larger interests of mainstream America.").

106. See, e.g., Brophy, Some Problems, supra note 1, at 499 ("A second factor leading to the reinvigoration of talk about reparations for slavery and Jim Crow are the models of reparations that other groups-Native Americans, Holocaust victims, Japanese Americans interned during World War II, South Africans-have obtained.").

107. Bert Neuborne, Holocaust Reparations Litigation, Lessons for the Slavery Reparations Movement, 58 N.Y.U. Ann. Surv. Am. L. 615, 621 (2003); Brophy, Some Problems, supra note 1, at 512 (noting that Holocaust recompense claims differ from slave reparations because "there are quite specific claims for identifiable property or specific torts.").

108. See Madeline Doms, Compensation for Survivors of Slave and Forced Labor: The Swiss Bank Settlement and the German Foundation Provide Options for Recovery for Holocaust Survivors, 14 Transnat'L Law. 171, 198-99 n.204 (2001) (noting provision for distribution to heirs of class members who are deceased, but only for those who die after the settlement date).

109. See generally Sebok, Two Concepts, supra note 16, at 1406-10 (discussing the litigation history of the Holocaust cases).

110. Neuborne, supra note 107 , at 621 .

111. Id. at 619 . 
keep the public eye on the issue until defendants chose to settle. ${ }^{112}$ Nevertheless, it is instructive to note that the Holocaust litigation, which many advocates see as a model for slave reparations, differs significantly in its vulnerability to attenuation arguments.

Other successful mass restitution cases are no more encouraging. The claims brought on behalf of Japanese internees did not suffer from victim attenuation; the claimants were the same people who had been interned. ${ }^{113}$ Similarly, the massive tobacco litigation, which resulted in a settlement, did not suffer from the same attenuation problems. ${ }^{114}$ The tobacco companies were the original harming parties, and the claimants were the original victims. Significantly, in some strands of related tobacco litigation that did introduce victim attenuation concerns, the cases were dismissed. For example, qui-tam-like claims $^{115}$ under the Medicare Secondary Payer Act, ${ }^{116}$ which suffered from conceptual separation similar to victim attenuation, were eventually dismissed. ${ }^{117}$

Indeed, the cases that have manifested all three kinds of attenuation are most striking for their failure to achieve a satisfactory resolution. Cases involving claims brought on behalf of Native Americans are similar to reparations cases in that they involve victim attenuation, act attenuation, and wrongdoer attenuation. These cases have not generally been successful. ${ }^{118}$ No generalized tort or human-rightsbased action for crimes against Native Americans has succeeded. Where Native American redress claims have succeeded, it has been on the basis of treaties signed with individual tribes. ${ }^{119}$ Of course, no such

112. Id. ("[T] he litigation was as much about politics as it was about law. . . . Law provided the roadmap [for settlement], but did not necessarily provide the fuel.").

113. See Hylton, Framework, supra note 14, at 32-33; Dale Minami, Japanese-American Redress, 6 Afr.-Am. L. \& Pol'y Rep. 27 (2004).

114. Some reparations advocates have suggested that the use of restitution theory to extract a settlement in the tobacco cases is a possible model for reparations. See Sebok, Two Concepts, supra note 16 , at 1406 .

115. These claims were brought by third parties on behalf of Medicare. As such, they are qui tam-like in nature, relying on the injury to a third party (the government). See Mason v. Am. Tobacco Co., 212 F. Supp. $2 d 88$ (E.D.N.Y. 2002) (discussing claims under Medicare Secondary Payer Act).

116. 42 U.S.C. $\$ 1395$ (b) (3) (A) (2000).

117. Claims under the Medicare Secondary Payer Act were brought to collect for tobacco-related expenses of patients paid by Medicare. See Mason v. Am. Tobacco Co., 212 F. Supp. $2 d 88$ (E.D.N.Y. 2002) (dismissing these claims).

118. See generally Lindsay Glauner, The Need for Accountability and Reparation: 1830-1976 the United States Government's Role in the Promotion, Implementation, and Execution of the Crime of Genocide Against Native Americans, 51 DePaul L. Rev. 911 (2002).

119. Mishael A. Danielson \& Alexis Pimentel, Give Them Their Due: An African-American Reparations Program Based on the Native American Federal Aid Model, 10 WASH. \& LeE RACE \& 
treaties exist in the slave context. Indeed, it is not an overstatement to say that no case that suffered from all three kinds of attenuation has successfully proceeded to a successful resolution through trial or settlement. This is a dire diagnosis for reparations.

It is questionable exactly how many types of attenuation can be present in a case before the case collapses. Obviously, one type alone can be fatal in some cases. But can a case ever succeed if it faces three types of attenuation? This is unclear. It may be possible to address one or more kinds, such as through efforts by reparations advocates to address wrongdoer attenuation by bringing suit against corporate entities. But as noted in that discussion, that solution only increased act attenuation. Is it possible to deal with all three types at once? That is the challenge that reparations advocates face, and it is a primary reason that reparations claims are failing today. Because of the presence of all three kinds of attenuation it is not clear that reparations litigation can ever succeed; if it does, it will be a trailblazer. It is sobering to note that only by overcoming attenuation in a truly unprecedented manner could reparations cases succeed in court.

Ultimately, however, reparations cases may not be best suited for success in court. ${ }^{120}$ Most of the major cases that reparations advocates often seek to emulate, including the Holocaust litigation, tobacco litigation, and suits for Americans of Japanese ancestry, succeeded not through judicial fiat but through negotiated settlement. ${ }^{121}$ Successful emulation of that model means keeping a court case alive in order to keep up consistent legal pressure while moral and political arguments are brought to bear. That court case, however, need not ultimately be a legal winner itself. The key for reparations at this juncture is to continue to advance ideas, particularly ideas that could counter the thorny problems created by attenuation.

ETHnic Anc. L.J. 89, 108 (2004) ("America has recognized a fiduciary duty towards Native American tribes pursuant to various treaty obligations and a network of statutes that impose certain specific responsibilities on the government."); Cato v. United States, 70 F.3d 1103, 1108 (9th Cir. 1995).

120. Many reparations advocates candidly admit that reparations are unlikely to be awarded at trial, and that the most fruitful route is through a legislative act or some sort of settlement. Westley, supra note 52, at 436 (arguing that it is Congress, and possibly state legislatures, that must be persuaded to enact reparations); Brophy, Some Problems, supra note 1, at 534-39 (noting need for development of dialogue and scholarship to address the possibility of settlement); Miller, supra note 10, at 51-57 (suggesting that settlement is more likely to be successful than litigation); Wenger, supra note 1, at 256-58 (same).

121. See Sebok, Two Concepts, supra note 16, at 1405-16 (noting history of tobacco and Holocaust litigation). 


\section{The Tools of Mass Torts Can Be Used to Address Attenuation in the Reparations Context}

It is very surprising that, despite the profound analogy between attenuation and similar concerns that come up in mass tort litigation, there has been very little discussion thus far of how to apply mass tort concepts in the reparations context. ${ }^{122}$ Courts and scholars have addressed complicated issues of causation in the mass tort context. Indeed, slavery itself can be viewed as one of the earliest mass torts.

This Part explores the analogy between reparations and mass torts. I do this as follows: Section A will examine similarities between causation issues in mass torts and in reparations, and Section B will discuss some of the issues of causation that arise in the mass tort context.

\section{A. Similarities Exist Between Reparations Concerns and Mass Tort Concerns}

Using the terminology of victim, wrongdoer, and act attenuation developed in Part II of this Article, we can see how the problems of attenuation that affect mass torts have much in common with those that plague reparations lawsuits. Mass tort litigation presents the same concerns of victim, wrongdoer, and act attenuation. In both cases, the real problem is the same: there is a potential connection between claimants and payers, but it is of undeterminable strength. It is hard to match the victim to the wrongdoer and to match the parties to the harm.

In fact, many mass tort issues could be reframed using the aforementioned categories of attenuation. For example, the problems of tracing a particular cancer to a defendant's product are created by act attenuation. The problem of identifying a culpable defendant from among a pool who have manufactured fungible products in a large market is a problem of wrongdoer attenuation. And the problem of connecting a harm to children and grandchildren of the originally harmed party-for example, the so-called "DES granddaughters"-is a problem of victim attenuation. In addition, there is the causation problem related to the victim attenuation concern of standing.

For example, the applicability of victim, wrongdoer, and act attenuation is visible in the litigation surrounding the drug diethylstil-

122. The major exception is Hackney, supra note 10, which briefly discusses some of these concepts. 
bestrol, better known as DES. ${ }^{123}$ DES was a drug commonly given to pregnant women over a period of time, and it ultimately proved to have deleterious effects on many of the children of those women. ${ }^{124}$ Litigants in the many strands of DES litigation faced victim attenuation defenses, since the daughters and granddaughters of women who took DES brought claims for harms done to them. ${ }^{125}$ Litigants also faced wrongdoer attenuation problems as in some cases it was difficult to trace DES pills to a particular manufacturer. Finally, litigants faced act attenuation concerns as they sought to link their harms to the drug. ${ }^{126}$ The mass tort issues as mapped onto an attenuation grid would follow along these lines: wrongdoer attenuation is similar to difficulties in tracing harm to a specific tortfeasor; ${ }^{127}$ victim attenuation is similar to the difficulty of tracing harm to later victims, particularly in cases such as the DES granddaughters; act attenuation is similar to the problem of linking harm to a defendant's actions.

As in the mass tort context, the harm to modern slave descendants caused by slavery is of underdetermined causation. Like the case of ships and safeguards, or in the case of DES granddaughters or Agent Orange veterans, we cannot know if a defendant's alternate choice not to enslave would have resulted in greater assets being given to any particular slave descendant. Since attenuated causation in reparations cases presents a problem analogous to that of mass torts, it is helpful to see how courts have addressed these issues in the mass torts context.

\section{B. Conceptual Tools in the Mass Torts Context That Address Causation}

Tort law in general, and mass torts in particular, have developed means of dealing with underdetermination. While attenuated causation may complicate the legal inquiry, it does not altogether rule out a

123. See Richard M. Russell, Note, The Causation Requirement: Guardian of Faimess or Obstacle to Justice? Making Sense of a Decade of DES Litigation, 25 SuFfolk U. L. Rev. 1071, 1071-81 (1991) (discussing DES litigation).

124. Id.

125. Ultimately, the litigants with the biggest victim attenuation problem, DES granddaughters, did not have great success in court. See infra note 146-147 and accompanying text.

126. Though for DES litigants, act attenuation was not a big hurdle as causation was established early for some harms. See Russell, supra note 123, at 1074-81.

127. Also, issues of wrongdoer attenuation may arise in addressing successor liability for damages. See generally Michael D. Green, Successor Liability: The Superiority of Statutory Reform to Protect Products Liability Claimants, 72 CoRnell L. Rev. 17 (1986) (discussing theoretical successor liability issues). 
finding of legal causation. This Section will discuss how tort law has dealt with attenuated causation through the application of various doctrines that permit recovery even in situations where the initial event in a chain of events is insufficient in bringing about a second event. That is, certain tort doctrines are sometimes used to overcome attenuation and permit recovery. Because they function in this way, they are of particular interest in the reparations discussion. The doctrine of loss of chance will be discussed in Section 1, burden shifting in Section 2, market share liability in Section 3, and substantial factor in Section 4. Finally, Section 5 will focus on the use of statistical evidence.

\section{Loss of Chance Theory Allows for Recovery Even Where Causation Is Underdetermined}

The tort system allows recovery in some underdetermined cases. ${ }^{128}$ A useful example is the imposition of liability for those ship owners that did not adequately protect against those sailors being washed overboard. In a well-known law review article, Wex Malone studied these cases and found that courts moved from a policy of not imposing liability to a policy of imposing liability nearly all of the time. ${ }^{129}$ Significantly, courts were willing to impose liability despite the conceptual difficulty of not knowing whether the victim would have been in a position to benefit from the increase in safety. ${ }^{130}$ According to Malone:

It would be futile for the courts to recognize a duty to provide emergency equipment and to impose an obligation to proceed promptly to the rescue if the defendant could successfully seize upon the uncertainty which nearly always attends the rescue operation as a reason for dismissing the claim. ${ }^{131}$

Tort scholars have suggested various theoretical approaches explaining why courts should allow liability even where causation is underdetermined. Malone refers to many of these cases as involving the loss of a "gambler's chance." 132 In such cases, a defendant facilitates

128. See Twerski \& Sebok, supra note 36, at 1381; Malone, supra note 31, at 72-73.

129. Malone, supra note 31, at 75-77.

130. Twerski \& Sebok, supra note 36 , at 1380; GraY, supra note 9 , at 97-100 \& n.18 (discussing cases).

131. Malone, supra note 31, at 77.

132. Id. at 80; see also Twerski \& Sebok, supra note 36, at 1381. The loss of the gambler's chance can be a significant loss. In many instances, without a defendant's actions, "some value would have been preserved ...." Malone, supra note 31 , at 80 . 
the realization of an independently created risk. ${ }^{139}$ That is, there is an independent risk of being washed overboard. However, the sailors would have a "gambler's chance" at survival if the ship owners implemented some basic safety measures. Courts are not always willing to find liability in gambler's chance cases, however, and are most willing to find liability in cases where a defendant had notice of a potential harm. ${ }^{134}$ Similarly, courts are more willing to find liability where defendants violated a rule "designed to protect" against the harm that in fact occurred. ${ }^{135}$ The gambler's chance lost by slave descendants is likely to be quite substantial. ${ }^{136}$

\section{Courts Can Employ Burden Shifting to Find Causation, Particularly Where Other Factors Are Present}

Burden shifting is also effective in many cases where neither causation nor non-causation can be definitively shown. ${ }^{137}$ Summers $v$. Tice ${ }^{138}$ is the classic case illustrating burden shifting and involved a hunting accident where it was impossible to determine which of two negligent shooters had caused the injury. ${ }^{139}$ The court held that "practical justice" allowed the burden to shift to the defendants and required them to establish that they were not the cause of harm. ${ }^{140}$

A similar approach appears in some mass tort cases. The court in Bichler v. Eli Lilly, ${ }^{141}$ a DES case, noted:

There have been several approaches in tort law available to a plaintiff confronted with more than one actor who could be the causation in fact. In such instances where each such party acted

133. Twerski \& Sebok, supra note 36, at 1383; see also id. at 1383-84 (giving examples); Robert L. Rabin, Enabling Torts, 49 DePaul L. Rev. 435, 439-48 (1999).

134. Twerski \& Sebok, supra note 36, at 1385-86.

135. Malone, supra note 31 , at 73 .

136. Hylton, Slavery, supra note 17, at 39 (suggesting that descendants might have an approximately forty percent chance of inheriting excess wealth from four generations removed).

137. Robinson, DES cases, supra note 31, at 721-26; GRAY, supra note 9, at 117-18 (discussing burden shifting).

138. 199 P.2d 1 (Cal. 1948).

139. Id. at 9-14; Robinson, DES cases, supra note 31, at 715. In Summers, the court ruled that both hunters could be held liable. Summers, 199 P.2d at 2; see also Malone, supra note 31, at 83 (stating that the court was unwilling to let "two wrongdoers . . pass the ball"); KEETON ET AL., supra note 9, at 271 ("It seems a very desirable solution where negligence on the part of both defendants is clear, and it is only the issue of causation which is in doubt, so that the choice must be made between letting the loss due to failure of proof fall upon the innocent plaintiff or the culpable defendants."); GRAY, supra note 9, at 102-04 (same).

140. Summers, 199 P.2d at 9-14.

141. 436 N.Y.S.2d 625 (App. Div. 1981). 
independently but tortiously and it is proved that injury has been caused to plaintiff by only one of them, but there is uncertainty as to which one caused it, and where each can be joined as a defendant in the case, some courts have shifted the burden of proof of causation in fact to the defendants. ${ }^{42}$

The Bichler court also found that since the defendants had acted in a similar manner and were aware of the possibility of harm, they could be held liable, even if the harm could not be directly traced to one particular defendant. ${ }^{143}$ Other DES courts have also adopted some version of group liability. ${ }^{144}$ This is similar to the idea of "enterprise liability," which was applied in other mass tort settings to find that all actors in an industry are liable for foreseeable harms. ${ }^{145}$

Courts have been divided in DES granddaughters cases with some courts allowing DES granddaughters to pursue claims against the DES manufacturers and other courts barring these claims. ${ }^{146}$ The burden shifting used by some DES courts is dispositive, since typically defendants are as unable to disprove causation as plaintiffs are unable to prove it. ${ }^{147}$

Scholars have suggested that courts are most likely to shift burdens, either explicitly or implicitly, and find liability in underdetermined causation cases where certain other factors are present. ${ }^{148}$ For example, courts are more willing to find liability if the tort is an intentional tort, or if the harm is easily foreseeable. ${ }^{149}$ Courts may reject cases where the chance of harm is particularly low. ${ }^{150}$ They

142. Id. at 630 .

143. Id. at $630-31$.

144. See, e.g., Collins v. Eli Lilly Co., 342 N.W.2d 37 (Wis. 1994); see generally Robert A. Baruch, Bush, Between Two Worlds: The Shift from Individual to Group Responsibility in the Law of Causation of Injury, 33 UCLA L. REv. 1473, 1493-97 (1986) (discussing several DES cases). This development has also been rejected by some courts. See, e.g., Payton v. Abbott Labs., 473 N.E.2d 171 (Mass. 1982).

145. See, e.g., Hall v. E. I. Du Pont De Nemours \& Co., 345 F. Supp. 353, 376 (E.D.N.Y. 1972).

146. John B. Maynard, Note, Third-Generation-DES Claims, 27 New ENG. L. REv. 241, 25l-6l (1992) (discussing cases); Bowe v. Abbott Labs., 608 N.E.2d 223 (Ill. App. Ct. 1992); Grover v. Eli Lilly \& Co., 591 N.E.2d 696, 700-01 (Ohio 1992) (denying recovery); Enright v. Eli Lilly \& Co., 570 N.E.2d 198, 204 (N.Y. 1991) (claim could not proceed because of preconception tort doctrine); DeMayo v. Schmitt, 5 Pa. D. \& C.4th 197 (C.P. Phila. County 1989) (allowing claim for negligence to be stated). See generally Julie A. Greenberg, Reconceptualizing Preconception Torts, 64 TENN. L. Rev. 315, 320-35 (1997) (discussing the cases).

147. Robinson, DES cases, supra note 31, at 729.

148. Twerski \& Sebok, supra note 36 , at $1381-86$.

149. Id. at 1381; Malone, supra note 31 , at 72-73, 85-87.

150. See Twerski \& Sebok, supra note 36, at 1387 (noting that the lower the probability that defendant's act was not a cause, the lower the probability of a court imposing liability); 
may also be likely to find liability where a party engaged in particularly noxious acts. ${ }^{151}$

\section{Market Share Liability Can Overcome the Attenuation Hurdle, Even Where Multiple Tortfeasors Exist}

Market share liability is a unique application of burden shifting. Sindell $v$. Abbott Laboratories ${ }^{152}$ used burden shifting, holding defendant DES manufacturers liable unless they could show that they did not cause plaintiffs' harm. ${ }^{153}$ The court held that since multiple actors contributed to the harm and causation was not individually traceable, all of the potential contributors could be held responsible. ${ }^{154}$ Sindell has been called a "modified Summers" case because it allowed the defendants to pay in proportion to the harm they caused. ${ }^{155}$ The court adopted reasoning similar to that in Summers, noting that "as between an innocent plaintiff and negligent defendants, the latter should bear the cost of the injury." 156 While market share liability may not apply in all cases, it remains an important way in which courts may shift the burden in cases where there are multiple defendants of varying levels of culpability. In such cases, courts may use market share to find in favor of the plaintiff even where the causative link is relatively weak. ${ }^{157}$

\section{Application of the Substantial Factor Test Can Overcome Overdetermined Causation}

Courts may also apply the "substantial factor" test to find causation, allowing liability in cases where a defendant's actions were a sub-

see also id. at 1387-90 (discussing the difficulty of dealing with low probabilities in a world of full compensation). The conceptual problem is that a court may be faced with two unpleasant choices: either to overdeter, or to allow defendants to escape liability entirely. Id.

151. See id. at 1386 (suggesting that the very production of handguns carries culpability); Rabin, supra note 133, at 453 (noting that handguns are designed for a dangerous purpose).

152. 607 P.2d 924 (Cal. 1980), cert. denied, 449 U.S. 912 (1980).

153. Robinson, DES cases, supra note 31 , at 717 . The court opted to make the DES manufacturers show that they did not cause the injury, rather than making the victims show causation. Id. at 714-15. The court adopted this position in part because it was easier for defendants to maintain the kind of data that could be used to either show, or disprove, causation. Id. at 734 .

154. Id. at 729 .

155. GRAY, supra note 9 , at $105-06$.

156. Sindell, 607 P.2d at 936 .

157. Cf. Russell, supra note 123, at 1102 ("That causation is a necessary element in any tort action is well accepted. But the experience of man and developments in society have prompted courts in the past to mitigate the consequences of strictly applying the causation requirement."). 
stantial factor leading to the plaintiff's harm. ${ }^{158} \mathrm{~A}$ defendant's actions will be considered a substantial factor in causing a harm if they "satisf[y] the but-for test (with an exception for simultaneous independent sufficient causes) [and are] an appreciable and continuously effective or efficient factor in producing the harm, up to the time of occurrence of the harm." 159 The substantial factor test allows courts to decide whether there is close enough affinity for the law to intervene and label a defendant's conduct "wrong." 160

Another useful analysis of substantial factor causation can be found in the district court opinion in Hamilton $v$. Accu-Tek, ${ }^{161}$ which dealt with a class action suit against handgun manufacturers for the harms caused by negligent distribution of handguns. ${ }^{162}$ The court asked whether defendants' conduct was a "significant contributing factor in the development" of a harm or "a substantial factor . . increasing the probability" of plaintiffs' harm. ${ }^{163}$ The underlying inquiry, as suggested by commentators, was "if defendants had behaved differently, how many fewer plaintiffs would have been harmed?"164

The substantial factor test can be a useful tool to allocate liability in cases involving overdetermined causation. Where a number of factors could each have created a harm, substantial factor analysis can be used to differentiate which factors should be considered in holding a defendant legally liable.

158. Malone, supra note 31, at 89-95 (discussing the substantial factor test).

159. Wright, supra note 8 , at 1781 ; see also Robinson, DES cases, supra note 31 , at 751 (noting that the substantial factor test is similar to the but-for test). One benefit of the substantial factor test is that it prevents minor causes from creating liability. Id. at 715-16.

160. Malone, supra note 31 , at 72 .

161. 62 F. Supp. 2d 802 (E.D.N.Y. 1999), rev'd on other grounds, 264 F.3d 21 (2d Cir. 2001).

162. Id.

163. Id. at 838 .

164. Twerski \& Sebok, supra note 36, at 1403-04. The judge noted that the defendants' conduct was a "significant contributing factor in the development" of the ultimate harm. Hamilton, 62 F. Supp. 2d at 838 . The evidence, wrote the court:

$[W]$ as sufficient to permit a reasonable jury to conclude that the negligent marketing and distribution of handguns by manufacturers was a substantial factor in the promotion and development of an underground illegal market supplying New York criminals, and thus increasing the probability of death or serious injury [to plaintiffs].

Twerski \& Sebok, supra note 36, at 1398. On the jury's role in assessing punishment, see generally Kaimipono David Wenger \& David A. Hoffman, Nullificatory Juries, 2003 WIS. L. Rev. 1115, 1148-56. 


\section{Statistical Evidence Can Provide the Necessary Association Between the Defendant's Act and the Plaintiff's Harm}

Faced with a variety of difficulties in showing causation in mass tort cases, advocates, scholars, and courts have developed methods for showing causation through statistical evidence. Scholars have argued that a "probabilistic approach to causation" is proper in cases where a large number of plaintiffs have been harmed by a group of defendants and where intervening causation is possible, resulting in an inability to definitely trace any individual plaintiff's injury to an individual defendant's actions. ${ }^{165}$ In these cases, scholars suggest that the amount recovered should be based on a "probability of causation" for a defendant. ${ }^{166}$

In In re "Agent Orange" Products Liability Litigation, ${ }^{167}$ Judge Weinstein suggested that plaintiffs would divide any recovery to reflect the statistical increase in likelihood of harm they suffered. To address a complex problem of underdetermination, Judge Weinstein applied statistical causation, using a type of proportional liability in allocating damages. ${ }^{168}$ Statistical, pro rata distribution of damages was used because of the problem of indeterminate defendants and indeterminate plaintiffs. ${ }^{169}$ Recognizing the relative novelty of this approach, the judge wrote: "We are in a different world of proof than that of the archetypical smoking gun. We must make the best estimates of

165. Robinson, DES cases, supra note 31 , at 759-60; Gold, supra note 42 , at 384 (noting that mass tort cases rarely involve particularistic evidence); Wendy Wagner, Note, TransScience in Torts, 96 YALE L.J. 428, 433 n.28 (1986) (collecting cases); Mario J. Rizzo \& Frank S. Arnold, Causal Apportionment in the Law of Torts: An Economic Theory, 80 Colum. L. Rev. 1399 (1980) (advocating the use of probabilistic causation in multiple cause cases).

166. Robinson, DES cases, supra note 31, at 766; see also Baruch, supra note 144, at 1490-92; Jack B. Weinstein \& Robert Kushen, Scientific Evidence in Complex Litigation, C-607 ALI-ABA Course of Study 709, 724 (July 24, 1991) (“Statistical data may . . permit combinations of anecdotal and valid statistical data to prove guilt or establish some material proposition of fact."). But of. Wright, supra note 8, at 1827 (suggesting that such devices may result in the tort system becoming more of a wealth redistribution system and less of a corrective justice system, and that such a change would be unfortunate).

167. 597 F. Supp. 740 (E.D.N.Y. 1984).

168. Id.; see also Peter H. Schuck, Agent Orange on Trial (1986) (describing the trial and resolution, including the process of arriving at settlement).

169. Agent Orange, 597 F. Supp. at 840-43. The court later wrote that causation could not be established to allow liability. See In re "Agent Orange" Prod. Liab. Litig., 611 F. Supp. 1223, 1229 (E.D.N.Y. 1985), affd, 818 F.2d 187 (2d Cir. 1987) (granting summary judgment to defendants against plaintiffs who had opted out of the certified class, since plaintiffs could not show a "causal link between exposure to Agent Orange and the various diseases from which they are allegedly suffering"); In re "Agent Orange" Prod. Liab. Litig., 611 F. Supp. 1267 (E.D.N.Y. 1985) (also granting summary judgment against an opt-out plaintiff), affd, 818 F.2d 187 (2d Cir. 1987). 
probability that we can using the help of experts such as statisticians and our own common sense and experience with the real universe." 170

The court's analysis is instructive. Judge Weinstein noted that it was quite possible that no particular plaintiff would be able to trace her injuries to a particular defendant and that only statistics would show any harm at all. He illustrated such a scenario:

Let us assume that there are 10 manufacturers and a population of 10 million persons exposed to their product. Assume that among this population 1,000 cancers of a certain type could be expected, but that 1,100 exist, and that this increase is "statistically significant," permitting a reasonable conclusion that 100 cancers are due to the product of the manufacturers. ${ }^{171}$

In such a case, Weinstein recognized, "no plaintiff can show that his or her cancer was caused by any one of the defendants . . ."172 The Agent Orange case was a clear instance of the underdetermined causation that is so common in mass torts. Similar concerns have dogged lawsuits seeking compensation for harm caused by products such as tobacco, asbestos, and DES. ${ }^{173}$

These concerns were also particularly acute in the DES litigation. ${ }^{174}$ DES was a drug that was used widely over a twenty-four year period, until it was found to cause reproductive illness in children of pregnant women who took the drug. ${ }^{175}$ DES was manufactured by a variety of companies, and many different types of DES tablets made by different manufacturers were interchanged freely. ${ }^{176}$ They were fungible products. Not only was it difficult to determine whether plaintiffs' injuries arose from DES; it was also difficult to trace the harm to any particular defendant. ${ }^{177}$ In most cases, claims were brought by daugh-

170. Agent Orange, 597 F. Supp. at 838; see also In re Joint E. \& S. Dist. Asbestos Litig., 52 F.3d 1124, 1131 (2d Cir. 1995) ("Causation in toxic torts normally comprises two separate inquiries: whether the epidemiological or other scientific evidence establishes a causal link between ' $c$ ' (asbestos exposure) and ' $d$ ' (colon cancer), and whether plaintiff is within the class of persons to which inferences from the general causation evidence should be applied."); Rosenberg, supra note 45 , at 859 (advocating proportional liability for defendants "in proportion to the probability of causation" of harm to the plaintiff class members). But cf. Wright, supra note 8, at 1822-23 (arguing that mere statistics, even when based on causal generalizations, cannot adequately show legal causation).

171. Agent Orange, $597 \mathrm{~F}$. Supp. at 837.

172. Id. at 838 .

173. See Anthony J. Sebok, Pretext, Transparency, and Motive in Mass Restitution Litigation, 57 VAND. L. REv. 2177, 2184-86 (2004).

174. See Russell, supra note 123 , at 1080 .

175. See generally Robinson, DES cases, supra note 31, at 718-19.

176. Id. at 722-26.

177. Id. 
ters of women who ingested DES. In some cases, claims were brought by granddaughters of the women as well. ${ }^{178}$ Statistical evidence was employed throughout the DES litigation to show a likelihood of harm to plaintiffs, thus establishing causation. ${ }^{179}$ Statistical evidence has been used in a variety of other mass restitution contexts. These include litigation related to tobacco, asbestos, Benedictin, and other products. ${ }^{180}$

Statistical causation in mass tort cases is generally shown by the use of epidemiological studies. ${ }^{181}$ These are used to "determine whether there is a statistical association between [a] defendant's product and [the] plaintiff's disease by comparing the incidence of disease in those exposed to [the] defendant's product with the disease's background rate." 182

178. See Maynard, supra note 146, at 285.

179. Tracey I. Batt, Note, DES Third-Generation Liability: A Proximate Cause, 18 CARdozo L. REv. 1217, 1219-22 (1996); see also James Brook, The Use of Statistical Evidence of Identification in Civil Litigation: Well-Worn Hypotheticals, Real Cases, and Controversy, 29 ST. Lours U. L.J. 293, 327-28 (1985).

180. As summarized by one scholar:

One way the causal link was made in the tobacco cases was the introduction of statistical methods of proof. Plaintiffs in the tobacco litigation were allowed to show that a widely distributed product increased the aggregate number of state residents who contracted a disease; such as lung cancer. In fact, this method of proving causation seems to be widely accepted in canc.r-related cases . . . In toxic-tort cases involving exposure to the drug Bendectin, as well as silicone, herbicides, and asbestos, courts have allowed statistical evidence to demonstrate causation where direct proof of causation was lacking.

See Angela Lipanovich, Comment, Smoke Before Oil: Modeling a Suit Against the Auto and Oil Industry on the Tobacco Tort Litigation Is Feasible, 35 Golden Gate U. L. Rev. 429, 463-64 (2005) (citations omitted).

181. Epidemiology is the branch of medical science that employs the integrated use of statistics "to identify and establish the causes of human diseases." See Bert Black \& David E. Lilienfeld, Epidemiologic Proof in Toxic Tort Litigation, 52 FordHaM L. REV, 732, 736 (1984). As one writer notes:

The hallmark of epidemiology is that it is based on the study of populations, not individuals. It seeks to establish associations between alleged causes and effects by one of two methods: either comparing the incidence of disease across exposed and unexposed populations, or comparing the incidence of exposure across sick and healthy populations. With proper scientific interpretation, these correlations lend great weight to an inference of causation.

Gold, supra note 42 , at $379-80$.

182. Berger, supra note 42, at 2125-26; see also Gold, supra note 42, at 384 (discussing the phenomena of increased risk and enhanced probability of harm). 


\section{The Application of Concepts Developed in Mass Torts in Overcoming Act, Victim, and Wrongdoer Attenuation in Reparations Suits}

The same doctrinal tools used in the mass tort context-loss of chance, burden shifting, market share liability, substantial factor, and statistical evidence-can be used to address legal attenuation concerns in reparations. Part V will examine the application of each of these tools to the three types of attenuation that this Article has introduced. In doing so, the Article will focus on ways that these established routes around attenuation might apply in the environment of reparations, and how they address the various attenuation concerns that arise.

\section{A. Tort-Based Reparations Claims}

\section{Confronting Reparations Challenges Based on Act Attenuation}

Overcoming the problem of act attenuation requires showing a link between the harm done to slaves and the harm to modern slave descendants. As in the mass tort context, statistical analysis can be one very helpful tool in showing this link. Other tort concepts like substantial factor can also play a role in showing a legal link between slavery and current harms.

Slave descendants could show a link between harm to slaves and later harms suffered by slave descendants through the use of statistical evidence on the economic effects of slave descent. ${ }^{183}$ The alleged harm to slave descendants is economic loss. It should be possible to establish whether slave descendants as a group have a lower rate of economic prosperity than the general populace. In particular, it would be helpful, if statistically possible, to compare prosperity levels of slave descendants against those of control groups, such as the descendants of free Blacks. A study could show that slave descendants as a group currently enjoy some ascertainable level of prosperity. Applying statistical tools, slave descendants could then seek to show whether, absent slavery, they would have attained a greater level of prosperity.

183. Cf. Twerski \& Sebok, supra note 36, at 1404, 1409 (suggesting that novel cases particularly benefit from the use of statistical data). Of course, such a study may be complex and difficult to perform. See Berger, supra note 42, at 2127-28 (noting the difficulty of conducting epidemiological studies). 
The existence of such a gap seems likely, given the well-known economic disparities between Blacks and members of other races. ${ }^{184}$ Statistical evidence could serve to put a number on that gap. Such application would probably involve, to adapt the language previously used by Judge Weinstein in the Agent Orange litigation, an examination along these lines:

Let us assume . . a population of 10 million persons exposed to [slave descent]. Assume that among this population 1,000 [persons below the poverty line] could be expected, but that 1,100 exist, and that this increase is "statistically significant," permitting a reasonable conclusion that 100 [persons below the poverty line] are due to the [slave descent]. ${ }^{185}$

Similar analysis could be done for various degrees of prosperity, allowing reparations advocates to put a solid number on the question of just how slaves' lost property and lost wages affect their descendants today. ${ }^{186}$ Adapting language from torts, slave descendants could thus show that slavery was a substantial factor in determining their prosperity level and that compensation is therefore appropriate.

Reparations advocates can also point to existing cases to suggest that slavery is the type of harm where burden shifting may be an appropriate response to underdetermination. The harms inflicted under slavery were intentional and not negligent, which is one indicator of potential liability. ${ }^{187}$ The harm against slaves and their children was also foreseeable - another potential indicator of liability. ${ }^{188}$ Negative effects on a victim's children are a logical result of severe wrongdoing. ${ }^{189}$ The very act of slavery carries an "air of culpability," which some commentators suggest is another indicator of liability. ${ }^{190}$ Other factors also weigh in favor of liability: slaves were subjected to inhu-

184. See supra note 52 (noting these statistics).

185. In re "Agent Orange" Prod. Liab. Litig., 597 F. Supp. 740, 837 (E.D.N.Y. 1984).

186. It is possible as well that statistics will weaken the case for reparations, for example, by showing that the harm to slave descendants is not as great as envisioned.

187. Twerski \& Sebok, supra note 36 , at 1385-86.

188. Id. (discussing how juries consider underdetermined causation cases given the foreseeability of harm).

189. To the extent that slave owners knew that they were harming slaves's children, note Posner and Vermeule, it may be unreasonable to view victim attenuation as an obstacle because slave descendants were a knowable victim themselves of slave owner wrongdoing. Posner \& Vermeule, supra note 10, at 700; see also Rosenberg, supra note 45 , at 884 ("But one could just as logically describe the defendant's duty in aggregative terms as a duty extending from the defendant to a class-the exposed population. Such a view suggests that the defendant's wrongdoing inflicts loss on the exposed population as a whole.").

190. See Posner \& Vermeule, supra note 10; see also Wenger, supra note 1, at 202 n.34 (noting the argument that slavery was a violation of natural law); Randy E. Barnett, Was 
man treatment, ${ }^{191}$ and an argument can be made that slavery was a valueless act. ${ }^{192}$

\section{The Loss of Chance and Statistical Evidence Doctrines Can Challenge Victim Attenuation Concerns to Overcome Standing and Causation Hurdles}

Tort concepts can also address victim attenuation concerns. Loss of chance doctrine provides a conceptual hook to show harm to plaintiffs. Statistical evidence could also be used to demonstrate concrete harm to slave descendants, thereby overcoming the standing hurdle and eventually the causation hurdle.

The conceptual underpinning for overcoming victim attenuation is simple enough. It is certainly true, as the Slave Descendants court noted, that any number of eventualities could have deprived plaintiffs from receiving economic benefits from their ancestors. ${ }^{193}$ The plaintiffs' ancestors may have chosen to spend their wealth on themselves $^{194}$ or donate it to charity. They may have chosen to give it to certain favored children, and plaintiffs' particular lines of parentage might have been unrepresented. Even if plaintiffs' ancestors had fully intended to pass on their wealth, they may have been unable to do so. They may have needed assets to deal with daily expenses or emergencies and had no money to pass on. They may have been poor money managers, losing their assets in unwise investments. ${ }^{195}$ They may have been victims of the many financial uncertainties that the country has seen, losing money to market crashes, business competition, changing laws, wars, speculation, financial panics, currency fluctuation, and inflation. ${ }^{196}$

Slavery Unconstitutional Before the Thirteenth Amendment?: Lysander Spooner's Theory of Interpretation, 28 PAC. L.J. 977, 988-1014 (1997).

191. See Malone, supra note 31, at 95 (noting that "inhuman treatment" was a factor in a court finding causation).

192. See id. at 86 (noting that courts are more likely to find causation if harmful act is not valuable to society). But cf. Wenger, supra note 1, at 239-40 (noting the economic value of slavery to the country).

193. See supra note 76 and accompanying text (labeling plaintiff's claim "conjectural").

194. This is a reasonable possibility. There is no indication that plaintiffs intend to pass on parts of any recovery to their descendants, rather than simply consuming it. See also Hylton, Slavery, supra note 17, at 1241 ("Precariousness would have given the slave a strong incentive to spend his money on his own desires right away.").

195. See id. ("The problem that remains is the passage of time, which allows for many opportunities for money to be squandered or used in other ways.").

196. Sherwin, supra note 23 , at 1445 ("[T]he passage of time and the countless human acts and choices that have intervened lead to daunting problems in tracing the injury to 
Every one of these is a possibility. And yet, it is also possible that these ancestors, had they been paid for their labor, would have passed down some amount of wealth, which would have eventually come to the plaintiffs. ${ }^{197}$ This is not an unrealistic scenario; many Americans enjoy some measure of inherited wealth. ${ }^{198}$ It is unrealistic to suggest that none of the slave descendants would have received inherited wealth. And therein lies the kicker-slave descendants can indeed show that they suffered a concrete harm, namely the loss of a chance. While they cannot show that they would ultimately have been the recipients of assets, this inability exists only because they never got the chance to receive assets in the first place. The lost chance suffered by slave descendants is a real and concrete harm. Showing the statistical likelihood of inheritance answers the recurring critique that the amount of compensation is not calculable. ${ }^{199}$

Statistical evidence can be used to show just how great of a chance slave descendants lost. Slave descendants will need to show the statistical likelihood of present claimants receiving wealth from slave ancestors, as well as the likely amount of any inheritance. Although accurately quantifying the loss of chance may be difficult, this number should be calculable. Armed with such a number, slave descendants can assert to a judge that they are not merely showing a genealogical relationship; by depriving their ancestors of compensation, slave own-

current generations of African Americans and separating the harm of enslavement from the effects of more recent public and private acts.").

197. As with other tort cases, the supposed breaks in the causal chain of harm to slave descendants are not particularly debilitating. In particular, the court is concerned that it cannot verify that slave ancestors would have given their assets to their descendants. This concern is overstated, given that bequeathing assets to descendants is the normal course of events. Hylton, Slavery, supra note 17, at 1241 ("To avoid reducing damages to descendants for a reason that was not only beyond the slave's control but a foreseeable consequence of the initial injury, we should assume that if paid, the slave would have passed the money on at the same rate as parents in conventional families do."). But cf. Waldron, supra note 87, at 10 (noting the "whimsical" nature of property disposition).

198. See generally Thomas M. Shapiro, The Hidden Cost of Being African-American: How Wealth Perpetuates Inequality (2004) (discussing transfer of wealth between generations); Westley, supra note 52, at 440-45 (discussing economic disparities between Blacks and whites).

199. See Richard Epstein, The Case Against Black Reparations, 84 B.U. L. Rev. 1177, 1186 (2004) ("We have no idea of how much of that profit (assuming that it could be calibrated) actually descended to the next generation. The ordinary business will reinvest some fraction of its profits, but will declare some as dividends and pay some out in salaries to its employees. Dividends and wages do not descend to the next generation."); Massey, supra note 10, at 164-65 ("[It] is impossible to know how much better off today's black Americans would be, if at all. It is even more speculative to try pinning a number on the loss suffered by any given contemporary individual descendant of American slavery."). 
ers deprived the slaves' descendants of a statistically measurable sum. ${ }^{200}$ Despite the possibility of intervening causes, plaintiffs have some statistically measurable, non-negligible chance of being the recipients of their ancestors' wealth. ${ }^{201}$ And it is almost certain that reparations defendants could not establish that they were not the cause of plaintiffs' injuries.

Even incomplete or preliminary statistical evidence should be enough to overcome the standing issue that proved fatal in Slave Descendants. The but-for connection between slavery and eventual harm to slave descendants is not in doubt; the only question is exactly how much worse slave descendants have fared compared to control groups. A court could apply loss of a chance doctrine, taking judicial notice that but for slavery, slave descendants today would enjoy greater prosperity. That admission, coupled with basic statistical evidence, could be used to show the level of harm required for standing.

The standing analysis reflected in the current Slave Descendants opinion is questionable and should be reconsidered. ${ }^{202}$ The court's standing analysis imposed on plaintiffs an unnecessarily high hurdle. ${ }^{203}$ Even reparations critics found the court's standing analysis

200. This number may be smaller than commentators assume. Indeed, economic studies suggest that, absent the presence of legal regimes to preserve wealth, it is difficult to keep fortunes together. See generally John F. Hart, "A Less Proportion of Idle Proprietors": Madison, Property Rights, and the Abolition of Fee Tail, 58 WASH. \& LEE L. REv. 167 (2001) (discussing the effect of fee tail and primogeniture in preserving wealth between generations). Ironically, Blacks missed out on many of the devices, such as fee tail and primogeniture, designed to maintain wealth. Thus, principles of corrective justice suggest that they should be given the benefit of every doubt on whether they would have kept wealth and passed it on to future generations.

201. Of course, the question might be complicated by the potential need for a Daubertapproved statistical model in order to show standing.

202. See Sebok, The Lawsuit, supra note 73, at 1-2; Epstein, supra note 199, at 1179-81; Eric J. Miller, Representing the Race: Standing to Sue in Reparations Lawsuits, 20 Harv. BLACKLETTER L.J. 91, 93 (2004).

203. In particular, the court may be requiring a showing of proximate cause, when all that is really required is a showing of but-for cause. See Richard H. Fallon, Jr., Of Justiciability, Remedies, and Public Law Litigation: Notes on the Jurisprudence of Lyons, 59 N.Y.U. L. REv. 1, 17-18 (1984); Calabresi, supra note 8, at 71-73 (discussing the difference between "three conceptions of 'cause': 'causal link,' 'but for cause,' and 'proximate cause'"); see also Aaron D. Twerski \& Neil B. Cohen, Informed Decision Making and the Law of Torts: The Myth of Justiciable Causation, 1988 U. ILL. L. REv. 607 (1988) (suggesting that courts generally insist on too high a burden of causation).

Prior to Lujan, standing could sometimes be established under rather attenuated theories of causation.

The [Supreme] Court has not ... required a showing of strict tort causation in the sense that the complained of conduct be the but-for cause of the plaintiff's harm. To the contrary, the Court has been willing to accept quite attenuated theories of causation, at least at the pleading stage. 
flawed; the court's decision is "little more than a disguised ruling on the merits," suggested one critic. ${ }^{204}$ The Slave Descendants court suggested that proximate causation must be fully established to show standing. That idea, however, is contrary to the law and the literature in this area. ${ }^{205}$

Of course, more detailed causal connection would ultimately be needed to establish liability. ${ }^{206}$ This would likely depend on a showing that slave descendants are statistically less prosperous than appropriate control groups. In any event, statistical tools would be invaluable in showing causation, both the basic causation level required to show standing, and the more rigorous showing that would be needed to establish liability. Other tort doctrines will also be useful at the liability stage. For example, it might make sense for a court to use a substantial factor test to determine liability. Statistics would play a major role in that inquiry as well, to show whether slave descent is indeed a substantial factor in determining the prosperity of slave descendants. The details of such an inquiry might include a comparison between the wealth, income, or education levels of slave descendants, versus the rest of the populace. Clear correlation between prosperity and slave

Karl S. Coplan, Refracting the Spectrum of Clean Water Act Standing in Light of Lujan v. Defenders of Wildlife, 22 Colum. J. ENvTL. L. 169, 185 (1997).

Lujan v. Defenders of Wildlife, 504 U.S. 555 (1992), applied a less forgiving eye to the standing requirement. Lujan, however, did not alter the basic inquiry. Id. at 560-61. In addition, Lujan sets forth a factual requirement to establish standing at the summary judgment stage. See id. at 561. Lujan stated that “[a]t the pleading stage, general factual allegations of injury resulting from the defendant's conduct may suffice, for on a motion to dismiss 'we presum [e] that general allegations embrace those specific facts that are necessary to support the claim." Id.

204. Epstein, supra note 199, at 1179-81. Courts are often accused of using standing to dodge serious issues. See, e.g., Cass R. Sunstein, What's Standing After Lujan? Of Citizen Suits, "Injuries," and Article III, 91 Mich. L. Rev. 163, 166 (1992); John A. Ferejohn \& Larry D. Kramer, Independent Judges, Dependent Judiciary: Institutionalizing Judicial Restraint, 77 N.Y.U. L. Rev. 962, 1009 (2002); Edward A. Hartnett, The Standing of the United States: How Criminal Prosecutions Show that Standing Doctrine Is Looking for Answers in All the Wrong Places, 97 Mich. L. REv. 2239, 2251-52 \& n.63 (1999).

205. Standing requires showing three elements: injury in fact, causal connection to a defendant, and redressability. Lujan, 504 U.S. at 560-61. This is a lesser burden than causation. As Richard Fallon argues, "the causation requirement of personal interest standing is not that of proximate cause. It seems instead to replicate the tort law concept of 'cause in fact' or 'but for' causation." Fallon, supra note 203, at 17 n.91; see also Epstein, supra note 199.

206. See Fallon, supra note 203, at 17-18 (discussing the difference between causation and standing requirements); Mark S. Brodin, The Standard of Causation in the Mixed-Motive Title VII Action: A Social Policy Perspective, 82 Colum. L. Rev. 292, 307 n.70 (1982) (noting this difference); Epstein, supra note 199, at 1181 (same). 
descent could show that slave descent is a substantial factor impacting slave descendants' prosperity.

\section{Sindell Provides a Framework for Overcoming Wrongdoer Attenuation}

Finally, the framework for apportioning liability set out in Sindell and other DES cases may provide a means of overcoming wrongdoer attenuation. In Sindell, the court found that DES manufacturers could be held liable despite the inability of plaintiffs to connect directly the manufacturers to the plaintiffs' harm. ${ }^{207}$ That court noted, "as between an innocent plaintiff and negligent defendants, the latter should bear the cost of the injury." 208 Similar reasoning applies in reparations: where the choice is between letting harm lie with descendants of innocent slaves, or with the corporate entities who participated in slavery, it makes sense to favor slave descendants. Sindell apportioned liability according to the market share of each defendant. ${ }^{209}$ That framework, if adopted in the reparations context, could potentially resolve many thorny distributional questions.

There are, however, significant conceptual hurdles that could imipede application of Sindell to reparations. In Sindell, the major players in the DES market-who collectively comprised a large majority of the relevant market actors-were all joined in the litigation. ${ }^{210}$ Because of this, the Sindell apportionment scheme seemed fair in a broad sensemost of the market was represented by the defendants joined in the case, and the only question was how to divide liability between apparently liable parties.

In contrast, market share liability in the reparations context is less compelling, precisely because it is not possible to join individual defendants representing even a majority of the slavery market. Certain long-lived individual corporate slave market participants still exist and are defendants in reparations litigation. ${ }^{211}$ It is all but certain, however, that the majority of the private actor participants in the slave

207. See supra notes $152-155$ and accompanying text.

208. Sindell v. Abbott Labs., 607 P.2d 924, 936-37 (Cal. 1980).

209. The Sindell court used proportional liability, allocating liability between the defendants in proportion to their market share. $I d$. at 936-38.

210. Id. at 936-37 (noting that joined defendants comprised ninety percent of the DES market).

211. Some of the corporate defendants include insurer Aetna, railroad company CSX, tobacco producer RJR Reynolds, and bank FleetBoston. On corporate liability in general, see Robinson, Comporate Responsibility, supra note 47, at 338-42; Miller, supra note 10, at 57-60. 
markets is no longer in existence or cannot be matched with any current defendant. Existing reparations defendants represent only a small percentage of the original slavery market. The market coverage of joined defendants in the reparations litigation thus differs drastically from the market coverage present in Sindell. Because of that difference, direct application of a Sindell framework is not possible without some kind of modification.

Various possibilities exist for adapting Sindell to the slavery market. One possibility would be to join government actors as additional defendants. This route has the benefit of creating a somewhat Sindelllike level of market coverage. Combined with corporate defendants, government actors could be viewed as comprising much of the slave market. Nevertheless, any attempt to join government actors runs into a host of problems, starting with sovereign immunity. ${ }^{212}$ In addition, it is not clear that joining government actors would actually result in a Sindell-like level of market coverage among the universe of joined defendants. Government and corporate entities played different and often overlapping roles in the slave market. It is not clear that adding government actors would alter the market coverage of joined defendants and make Sindell application any easier.

Another possibility would be to hold currently joined reparations defendants liable for the acts of other participants in the slave market, who have not been joined in the litigation. This approach is similar to "enterprise liability" theories, which hold that any actors in an enterprise can be found liable for harms it causes. ${ }^{213}$ Under such a system, individual corporate actors could be held liable not only for their own share of the original market, but also for the market share of the many other actors no longer in existence. This would result in much greater potential monetary recovery for plaintiffs since no portion of the original market would be written off as judgment proof. Such a framework raises potentially insuperable questions of fairness, though, because it imputes to existing defendants the shares of judgment proof former market participants.

Finally, Sindell could be adapted in a more limited fashion to allow for pro rata recovery according to the market share of existing defendants. Under such a system, each defendant would be liable for its own portion of the original market for slavery, as defendants in

212. See generally Wenger, supra note 1, at 243-49 (discussing government defenses against reparations claims).

213. See Hall v. E. I. Du Pont De Nemours \& Co., Inc., 345 F. Supp. 353, 368 (E.D.N.Y. 1972); WeInSTEIN, supra note 45 , at 149-52 (discussing enterprise liability). 
Sindell were liable for their portions of the DES market. However, those portions of the initial market not represented by current defendants-almost certainly the vast majority of the market for slavery-would simply be written off as uncollectible. Thus, if slave descendants can join defendants representing $10 \%$ of the slave market, then they can collect damages representing $10 \%$ of the economic harm suffered by slave descendants. The remaining $90 \%$ would be attributable to non-collectable (perhaps non-existent) entities. This approach would provide a lower level of potential monetary recovery to slave descendants, since the majority of claims would be written off as uncollectible. Those would be the claims attributed to participants in the original market, who are not joined to the current litigation. However, because this modification would not force any defendant to pay for harm greater than its percent of market share, it is the least problematic route from a fairness standpoint.

\section{B. Unjust Enrichment Claims Similarly Benefit from Use of Mass Tort Doctrinal Tools}

Although the foregoing analysis is addressed in torts, much of it would apply to unjust enrichment claims as well. For example, unjust enrichment claimants could use statistical evidence to attack victim attenuation arguments. In addition Sindell-like market share restitution would be a way of avoiding wrongdoer attenuation in unjust enrichment cases, as well as in tort cases.

The possibility of apportioning liability according to market shares is particularly attractive in the unjust enrichment context. Some scholars believe that unjust enrichment claims are the best opportunity for reparations. ${ }^{214}$ Unjust enrichment offers significant advantages. For example, it offers a lower threshold of proof-a litigant need merely show that it is more likely than not that a defendant was unjustly enriched. ${ }^{215}$ Violation of law need not be shown-as Emily Sherwin notes, "[o]n its face, the term unjust enrichment reaches beyond what is illegal to what is simply unjust. Therefore, unlike compensation, unjust enrichment can be read to cover conduct that was morally wrong although sanctioned by law." 216 As others have noted, however, unjust enrichment claims run into difficulty at the remedy stage. ${ }^{217}$ The question of how to apportion blame is not at all clear.

214. See, e.g., Sebok, Prosaic Justice, supra note 23, at 52.

215. Sherwin, supra note 23 , at 1447-53.

216. Id. at 1448 .

217. Sebok, Two Concepts, supra note 16, at 1431-40. 
Thus, while unjust enrichment can answer some of the problems inherent in tort claims, they do not provide a clear avenue for remedy.

Sindell market share apportionment may be the best way to convert unjust enrichment claims from academic fantasy into legal reality. If market share liability provides a solution to the tracing problem, unjust enrichment claims may become more viable. Like the DES case addressed in Sindell, unjust enrichment claims run into the problem of tracing. But also like Sindell, the harm alleged is largely fungible. In Sindell, market share liability was feasible because all of the manufacturers had contributed to a nationwide pool of DES and the harm was largely fungible. Injury from slave descent is similarly fungible, and all defendants contributed to the formation of the nationwide system of enslavement. Thus, market share liability in unjust enrichment is appropriate. This solution is attractive because it is easy to implement. It skips thorny theory questions at the implementation stage, offering a viable method to calculate each defendant's contribution.

Finally, unjust enrichment claims might also benefit from statistical analysis. Victim and act attenuation problems in unjust enrichment, like in tort, can be addressed through the use of statistical evidence. That is, slave descendants could show that a harm was done to them and can be statistically shown, and that that harm is linked to acts of enslavement that provided a benefit of unjust enrichment to defendants. Unjust enrichment requires a showing of "a benefit conferred upon the defendant by the plaintiff." ${ }^{18}$ Statistical evidence may provide the necessary link between defendants' acts and plaintiffs' harm, allowing an unjust enrichment claim to prevail.

\section{Recap}

This Part has examined the idea of causation in the reparations context and has offered suggestions on how to overcome the attenuation hurdle in the litigation process. It is apparent that legal attenuation critiques, including the Slave Descendants court's analysis, are oversimplified. The question of causation in reparations requires analysis of underdetermined causation which does not always preclude liability. Reparations advocates should use the tools of mass tort, particularly statistical causation, to establish liability. Statistical tools may be used to show harm to modern claimants, resolving legal concerns of victim and act attenuation and addressing standing problems. Conceptual tools used in the DES and other cases, including modified

218. Hylton, Slavery, supra note 17 , at 1427. 
Sindell-style market share liability, can also be used to address wrongdoer attenuation.

\section{Conclusion}

Much remains to be done. Reparations advocates must test statistical causation arguments to see if they satisfy courts' lack of harm and standing concerns. The arguments should be further developed and refined for use in showing causation at trial, ultimately addressing act attenuation concerns that may arise at that stage. The Sindell harm contribution analysis should be employed as needed to address wrongdoer attenuation.

Future steps might include tying these causal tools to particular proposals for asset distribution. It is nearly impossible to discuss reparations today without at least a nod to the many distribution critiques raised by critics. ${ }^{219}$ Questions of direct or group compensationthemselves beyond the scope of this Article-will eventually need to be answered. However, these may also eventually turn out to be questions best answered by examining the mass tort experience, with its models for distribution to victims. ${ }^{220}$

Despite the work that remains to be done, this Article shows that theoretical tools from the mass tort context may be helpful in addressing attenuation in the reparations debate. Indeed, it turns out that attenuation, like many other concerns about reparations, may provide "grist for the mill of reparations critics, but ... [is] familiar in law, and the law has developed methods for dealing with (or ignoring) [it]."221

219. See generally Wenger, supra note 1, at 253-56 (noting different proposals for distribution of reparations); Kyle D. Logue, Reparations as Redistribution, 84 B.U. L. Rev. 1319, 1354-70 (discussing different models of distribution).

220. See Weinstein, supra note 45, at 155-62.

221. See Posner \& Vermeule, supra note 10, at 702 (making this statement about potential problems in determining compensation amounts and in making any distribution of restitution). 